\title{
Overexpression of stathmin plays a pivotal role in the metastasis of esophageal squamous cell carcinoma
}

\author{
Gaijing Han ${ }^{1, *}$, Zongyong Wu ${ }^{2, *}$, Nan Zhao ${ }^{1}$, Lanping Zhou ${ }^{1}$, Fang Liu ${ }^{1}$, Fangfei Niu ${ }^{1}$, \\ Yang $\mathrm{Xu}^{1}$ and Xiaohang Zhao ${ }^{1}$ \\ ${ }^{1}$ State Key Laboratory of Molecular Oncology, National Cancer Center/Cancer Hospital, Chinese Academy of Medical Sciences \\ and Peking Union Medical College, Beijing, China \\ ${ }^{2}$ Clinical Laboratory, National Cancer Center/Cancer Hospital, Chinese Academy of Medical Sciences and Peking Union Medical \\ College, Beijing, China \\ "The authors have contributed equally to this work \\ Correspondence to: Yang Xu, email: xuyang@cicams.ac.cn \\ Xiaohang Zhao, email: zhaoxh@cicams.ac.cn
}

Keywords: stathmin, integrina5 $31, F A K$, ERK, ESCC

Received: November 30, $2016 \quad$ Accepted: May 23, $2017 \quad$ Published: June 27, 2017

Copyright: Han et al. This is an open-access article distributed under the terms of the Creative Commons Attribution License 3.0 (CC BY 3.0), which permits unrestricted use, distribution, and reproduction in any medium, provided the original author and source are credited.

\section{ABSTRACT}

Purpose: Esophageal squamous cell carcinoma (ESCC) is a serious malignant tumor that affects human health. We analyzed the correlation between serum stathmin level and ESCC and elucidated the molecular mechanisms of stathmin's promotion of ESCC cell invasion and metastasis.

Methods: Stathmin level in ESCC and healthy control serum were detected by enzyme-linked immunosorbent assay (ELISA), and the clinical parameters were analyzed. We established ESCC cells with stathmin overexpression or knockdown and then evaluated the effects of stathmin on invasion and metastasis in ESCC. Differentially expressed genes were analyzed by Human Transcriptome Array and confirmed by RT-PCR. The expression levels of the integrin family, focal adhesion kinase (FAK) and extracellular signal-regulated kinase (ERK) were detected by immunoblotting.

Results: Serum levels of stathmin were significantly higher in ESCC than in control serum and associated with lymph node metastasis, tumor stage and size. Furthermore, we found that stathmin promoted migration and invasion of ESCC cells in vitro and in vivo. In addition, we confirmed that the activation of the integrina5 $\beta 1 /$ FAK/ERK pathway is increased in stathmin-overexpression cells and accelerates cell motility by enhancing cell adhesion ability.

Conclusion: Stathmin may predict a potential metastasis biomarker for ESCC.

\section{INTRODUCTION}

Esophageal cancer (EC) is the eighth most common malignant cancer and the sixth most common cause of cancer deaths worldwide; it seriously affects human health [1]. Esophageal squamous cell carcinoma (ESCC) accounts for approximately $90 \%$ of EC cases in developing countries. The prevalence of ESCC varies geographically and is highest in China, Southeast Africa and Japan [1,2]. The clinical features of ESCC include a lack of obvious early symptoms, a lack of serum detection markers of sufficient sensitivity and specificity, and poor prognosis. Current treatment for ESCC includes surgical resection, radiotherapy and chemotherapy [3]. Metastasis is primarily responsible for ESCC mortality, yet the molecular mechanism of metastatic dissemination remains unclear [4]. Clinical studies have found that ESCC spreads through the lymph and blood; the most common metastatic site is the lung, followed by the liver, bone and brain. Most patients have local or distant lymph node metastases at surgery $[5,6]$. 
The microtubule is involved in many biological processes, such as cell cycle progression, cell proliferation, intracellular signal transduction, the transport of substances and cell movement [7]. Stathmin is a microtubuledestabilizing protein and is also known as oncoprotein 18 (Op18); it binds to $\alpha, \beta$-tubulin heterodimers and regulates microtubule dynamics [8, 9]. In 1982, Schubart found stathmin in hamster insulinoma cells. In 1988, stathmin was found to be overexpressed in acute leukemia cells, and this discovery was the first identified association of stathmin with human malignancies $[10,11]$. There is increasing evidence that stathmin is related to a variety of tumors, such as endometrial, breast, melanoma, gastric, ovarian and bladder cancers. Stathmin is highly expressed in cancerous tissues, and its level is associated with tumor drug resistance, metastasis, recurrence, and prognosis [1218]. Therefore, stathmin may be a therapeutic target for a variety of tumors.

Previously, our laboratory used matrix-assisted laser desorption/ionization time of flight mass spectrometry (MALDI-TOF-MS) to analyze the differential proteomic expression profiles of 8 pairs of ESCC and adjacent normal tissues. The results showed that the expression of stathmin was higher in ESCC tissues than in adjacent normal tissues. We then analyzed stathmin expression in 143 ESCC tissues using immunohistochemistry. The results indicated that stathmin expression was relatively high in ESCC tissues and negatively correlated with the degree of ESCC differentiation [19]. Wang et al. also found stathmin overexpression in ESCC, which was associated with lymph node metastasis, TNM stage and other clinical parameters [20]. Akhtar et al. demonstrated that the 5-year survival was significantly lower in ESCC patients with high stathmin than in those with low stathmin, which indicated that stathmin could be used as a marker for ESCC prognosis [21, 22]. However, studies on the mechanisms of overexpression and the serum levels in ESCC are limited. We investigated whether stathmin overexpression is associated with metastasis and whether stathmin serum level represents a potential tumor marker for ESCC.

In this study, our main goals are to evaluate the serum level of stathmin and explore the previously uncharacterized role of stathmin overexpression in promoting the migration and invasion of esophageal cancer cells. In addition, we considered whether stathmin could be a potential metastasis marker for ESCC diagnosis.

\section{RESULTS}

\section{Clinical significance of serum stathmin in ESCC}

ELISA analysis showed that the concentration of stathmin in ESCC patients was significantly elevated $(\mathrm{n}=535$, mean $5.98 \mathrm{ng} / \mathrm{ml}$, standard deviation $(\mathrm{SD}) \pm 2.89$ $\mathrm{ng} / \mathrm{ml}$ ) compared with the concentration in healthy controls ( $\mathrm{n}=288$, mean $2.16 \mathrm{ng} / \mathrm{ml}, \mathrm{SD} \pm 1.19 \mathrm{ng} / \mathrm{ml}, P<$ 0.001) (Figure 1A). Receiver operating characteristic (ROC) curves were used to establish the sensitivityspecificity relationship for stathmin (Figure 1B). The area under the curve (AUC) was 0.924, and the cut-off level determined by the Youden index was $3.014 \mathrm{ng} / \mathrm{ml}$. The sensitivity of stathmin in detecting ESCC was $88.6 \%$ at a specificity of $80.6 \%$. The correlation analysis of clinic pathological data with stathmin (Table 1) using cross tabulation in 535 patients showed a significant positive association between stathmin level and tumor size $(>5 \mathrm{~cm}$ vs. $<5 \mathrm{~cm})(6.10 \pm 3.00 \mathrm{ng} / \mathrm{ml}$ vs. $5.41 \pm 2.43 \mathrm{ng} / \mathrm{ml}, P<0.05)$. Significantly higher levels were observed in patients with lymph node metastasis than in those without $(6.14 \pm 2.85$ ng/ml vs. $5.67 \pm 2.94 \mathrm{ng} / \mathrm{ml}, P<0.005$ ) (Figure $1 \mathrm{C}$ ). ELISA also showed that stathmin expression escalated with clinical stage from I+II to III+IV $(6.40 \pm 2.91 \mathrm{ng} / \mathrm{ml}$ vs. $5.72 \pm 2.75 \mathrm{ng} / \mathrm{ml}, P<0.05$ ) (Figure 1D). Additionally, serum levels of stathmin were measured in other patients include head and neck cancer, colorectal cancer, gastric cancer and hepatocellular carcinoma, the results showed that the stathmin concentration was higest in head and neck cancer $(8.88 \pm 4.34 \mathrm{ng} / \mathrm{ml})$ and lowest in colorectal cancers $(5.24 \pm 2.34 \mathrm{ng} / \mathrm{ml})$ (Figure 1E). In conclusion, these results suggest that stathmin may act as a biomarker for the clinical detection of ESCC and can be used in the diagnosis of lymph node metastasis.

\section{Stathmin overexpression promotes ESCC cell metastasis}

To confirm the role of stathmin overexpression, seven human esophageal cancer cells were tested by western blot. As shown in Figure 2A, among the cell lines, the KYSE 30 and KYSE 170 ESCC cells showed the lowest stathmin expression. Therefore, the KYSE 30 and KYSE 170 cells were used for the overexpression experiments and KYSE 510 cell were knocked down. After transfection of KYSE 30 and KYSE 170 cells with the STMN1 plasmid (KYSE 30-STMN1/KYSE 30-Ctrl, KYSE 170-STMN1/KYSE 170-Ctrl), we found overexpression of stathmin compared with the expression level of the control group (Figure 2B and 2C). KYSE 510 cells were used for stathmin knocked down experiments. After transfection with two different STMN1 specific siRNAs (siRNA-1 and siRNA-2), a reduction in stathmin protein expression was observed relative to negative control (NC) siRNA-treated cells (Supplementary Figure 1A).

To determine whether stathmin level might affect cellular invasion, transwell assays were performed. As shown in Figure 2D and 2E, stathmin overexpression was associated with significantly increased cellular invasion compared with the level in the control group. In contrast, STMN1-knockdown by siRNA in KYSE510 cells 
A

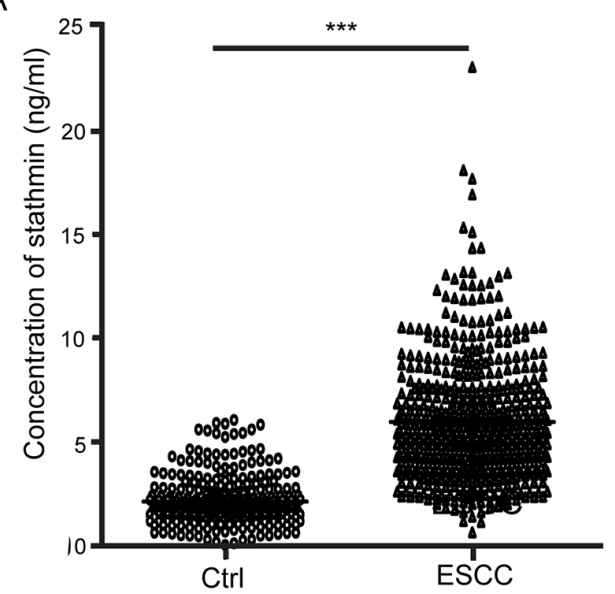

C

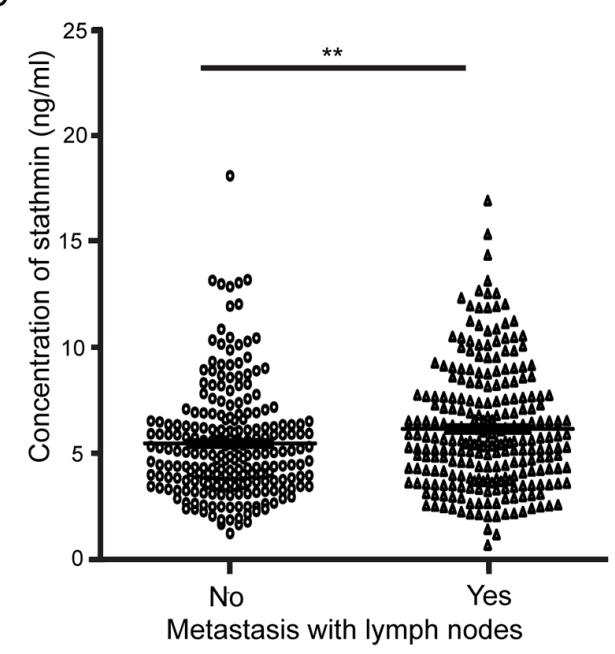

$\mathrm{E}$

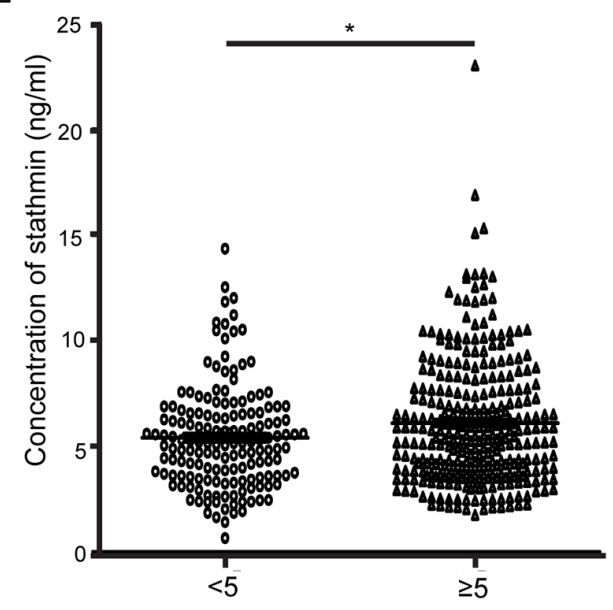

B

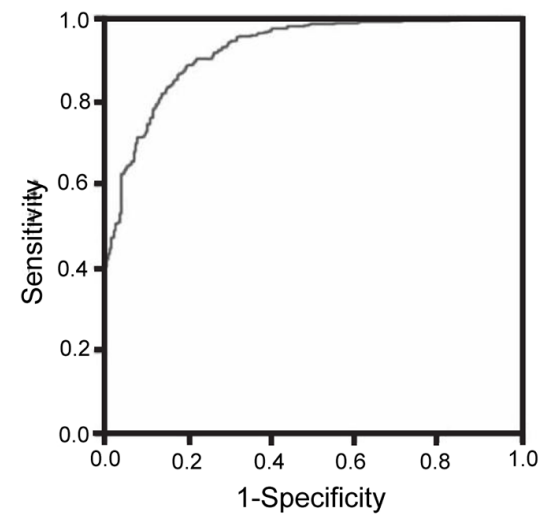

D

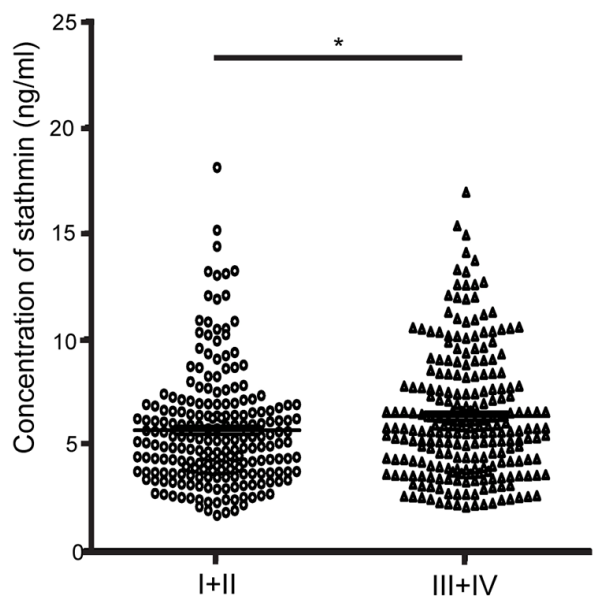

$\mathrm{F}$

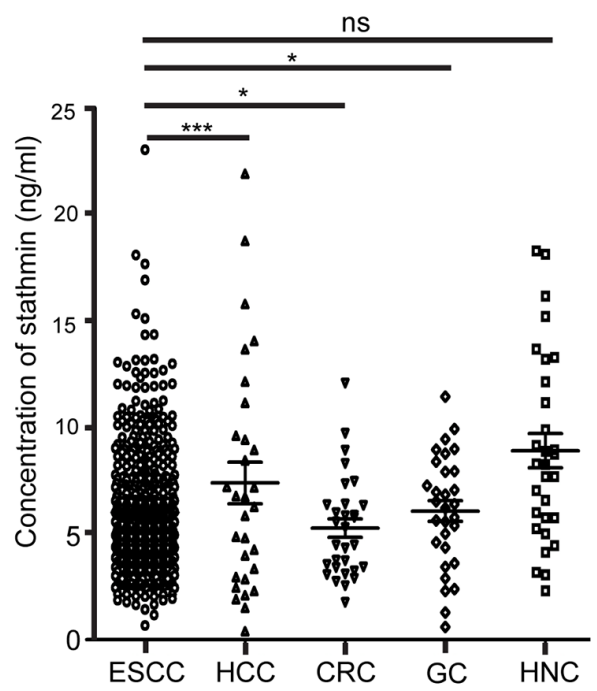

Figure 1: Clinical significance of serum stathmin in ESCC. (A) The concentration of stathmin in ESCC patients was significantly higher than that in healthy controls $(P<0.0001)$. (B) ROC curve analysis of the sensitivity and specificity of serum stathmin in ESCC and healthy controls $(P<0.005)$. (C) Stathmin levels in ESCC lymph node metastasis were significantly higher than those in non-metastatic $(P<0.05)$. (D) Stathmin levels in ESCC stage III+IV were higher than those in stage I+II $(P<0.005)$. (E) Comparison of stathmin levels among different cancers, include ESCC, hepatocellular carcinoma (HCC), colorectal cancer (CRC), gastric cancer (GC) and head and neck cancer (HNC). 
Table 1: Correlation between serum stathmin levels and clinicalpathological features

\begin{tabular}{|c|c|c|c|c|}
\hline \multirow[t]{2}{*}{ Parameter } & \multirow[t]{2}{*}{ Group } & \multirow[t]{2}{*}{$\mathbf{N}$} & $\begin{array}{c}\text { Levels serum } \\
\text { stathmin }(\mathrm{ng} / \mathrm{ml})\end{array}$ & \multirow[t]{2}{*}{$P$} \\
\hline & & & Mean \pm SD & \\
\hline ESCC patients & & 535 & $5.98 \pm 2.89$ & $<0.001$ \\
\hline Healthy control & & 288 & $2.16 \pm 1.19$ & \\
\hline \multicolumn{5}{|l|}{$\begin{array}{l}\text { Lymph nodes } \\
\text { metastases }\end{array}$} \\
\hline & Yes & 221 & $5.48 \pm 2.61$ & $<0.005$ \\
\hline & No & 248 & $6.14 \pm 2.85$ & \\
\hline \multicolumn{5}{|l|}{ Tumor stage } \\
\hline & $\mathrm{I}+\mathrm{II}$ & 209 & $5.72 \pm .72 \mathrm{I}$ & $<0.05$ \\
\hline & $\mathrm{III}+\mathrm{IV}$ & 233 & $6.40 \pm 2.91$ & \\
\hline \multicolumn{5}{|l|}{ Tumor size } \\
\hline & $<5 \mathrm{~cm}$ & 158 & $5.41 \pm 2.43$ & $<0.05$ \\
\hline & $\geq 5 \mathrm{~cm}$ & 302 & $6.10 \pm 3.00$ & \\
\hline \multicolumn{5}{|l|}{ Pathological grade } \\
\hline & poorly & 73 & $6.25 \pm 2.88$ & 0.337 \\
\hline & Moderately & 267 & $5.91 \pm 2.91$ & \\
\hline & well & 118 & $5.89 \pm 2.95$ & \\
\hline \multicolumn{5}{|l|}{ Gender } \\
\hline & Male & 438 & $6.18 \pm 2.91$ & $<0.001$ \\
\hline & Female & 97 & $5.08 \pm 2.61$ & \\
\hline \multicolumn{5}{|l|}{ Ages } \\
\hline & $\geq 50$ & 477 & $5.88 \pm 2.86$ & $<0.05$ \\
\hline & $<50$ & 58 & $6.78 \pm 3.0$ & \\
\hline
\end{tabular}

effectively reduced the populations of transwell invasive cells compared with the populations in the control group (Supplementary Figure 1B and 1C). Relative motility was tested by wound-healing assay, as shown in Figure $2 \mathrm{~F}$ and $2 \mathrm{G}$. Stathmin overexpression promoted cell migration in KYSE170 and KYSE30 cells, which overexpressed stathmin (Figure 2B and 2C). Furthermore, in knockdown STMN1 experiments, the relative motility of cells treated with STMN1-siRNA was significantly decreased compared with that of the NC group (Supplementary Figure 1C). To determine the ability of a cell to proliferate indefinitely after an alteration in stathmin level, we performed a colony-formation assay with KYSE170 cells. The colony-formation capacity was enhanced in KYSE 170 cells compared with that in the control group (Supplementary Figure 2A). To confirm that the observed increase in migration was not in fact an increase in cell proliferation, mitomycin $\mathrm{C}$ was used to inhibit cell proliferation during the cell wound-healing assay. We found that the relative motility of the STMN1 group was significantly increased compared with the control group (Supplementary Figure 2B). Taken together, our results indicated that stathmin overexpression enhanced the invasion, migration and proliferation of ESCC cells.

\section{Gene expression changes in ESCC cells with stathmin overexpression}

To characterize the molecular pathways affected by stathmin in ESCC cells, we used the Human Transcriptome Array (HTA2.0) to perform microarraybased global gene expression profiling of KYSE 170 cells with exogenous increased stathmin expression. Global gene expression profiling of KYSE 170-Ctrl and KYSE 170-STMN1 cells was conducted using a microarray platform. Significantly differential genes expression were found, including 63 upregulated and 27 downregulated genes (Figure 3A). The results of the STRING enrichment 
analysis are shown in Figure 3B. Sixty-three upregulated genes (indicated by red on the heat map) were found to be functionally enriched in gene ontology categories extracellular region and cellular component. Using the DAVID database, we found that stathmin might increase a wide range of cellular adhesion molecules, which would be consistent with the higher malignancy of cancer cells with stathmin overexpression (Figure 3C). To validate differentially expressed genes in KYSE170 cells, several genes associated with cell adhesion and cytoskeleton were verified by real-time PCR, including KRT6C, KRT15, KRT17, KRT13, ARP2/3, GBP1, NT5E, GALN5, FN, LYPD3, CLCA2, FAK, RASSF5 and CEACAM5. The mRNA levels of FN, LYPD3, CLCA2, FAK, RASSF5 and CEACAM5 were highly upregulated in the STMN1 group (Figure 3D).

A

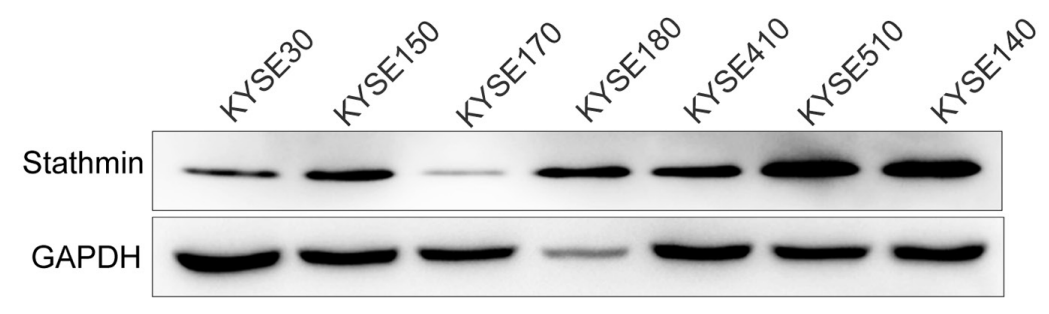

B

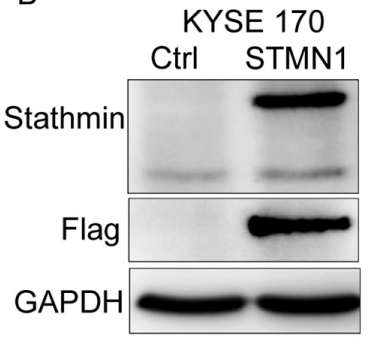

D

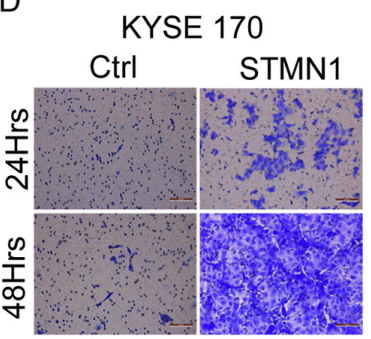

$\mathrm{F}$

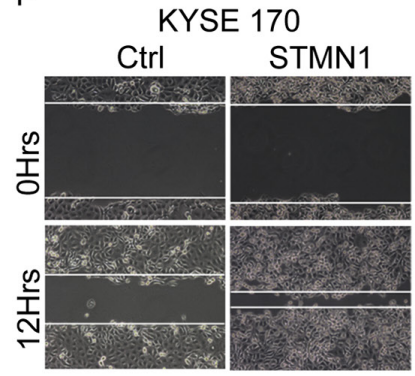

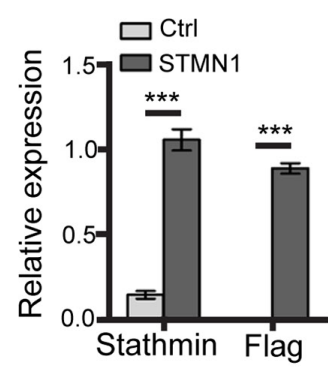

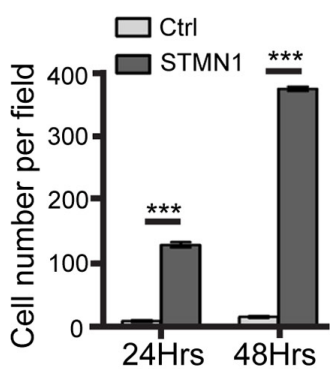

$E$

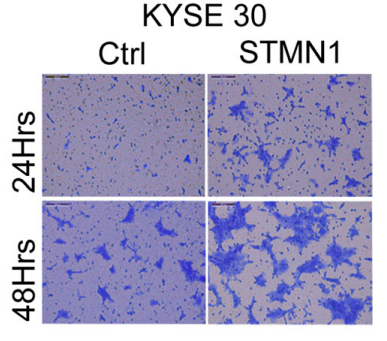

G

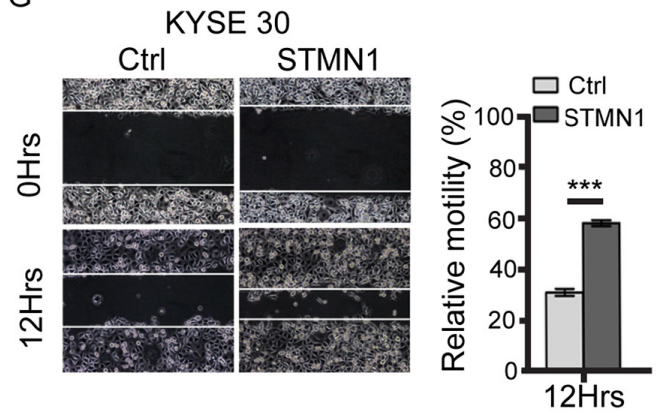

Figure 2: Stathmin promoted ESCC cell invasion and migration. (A) Stathmin expression in seven ESCC cell lines was examined by western blotting. GAPDH was used as a loading control. (B, C) Immunoblotting was used to analyze the stathmin protein level in KYSE 170 and KYSE 30 cells. Control (Ctrl) represents KYSE 170 or KYSE 30 cells transfected with the control plasmid; STMN1 represents KYSE 170 or KYSE 30 cells transfected with STMN1-plasmid. (D, E) The transwell invasion system demonstrated an enhanced invasion capacity of the KYSE 170 and KYSE 30 stathmin-overexpression groups compared with controls. Images of invading cells were captured by phase contrast microscopy at $200 \times$ magnification. The y-axis represents the number of invading cells. (F, G) A wound-healing assay was performed to investigate the migratory potential of KYSE 170 and KSYE 30 cells after stathmin levels changed. In the quantitative migration assay results, the y-axis represents the migration rate relative to that of control cells. Stathmin overexpression significantly promoted the migration ability of both cell lines. All assays were replicated, and results are presented as the mean $\pm \mathrm{SD}(*, P<0.05)$. 
A
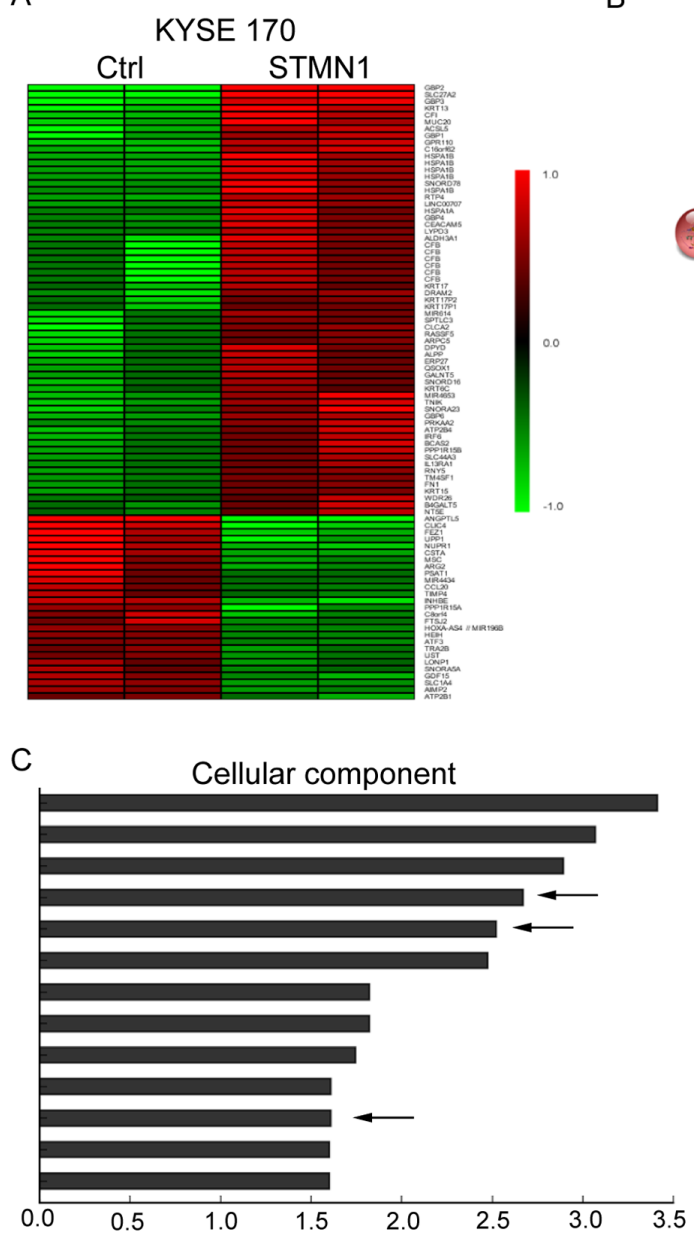

B

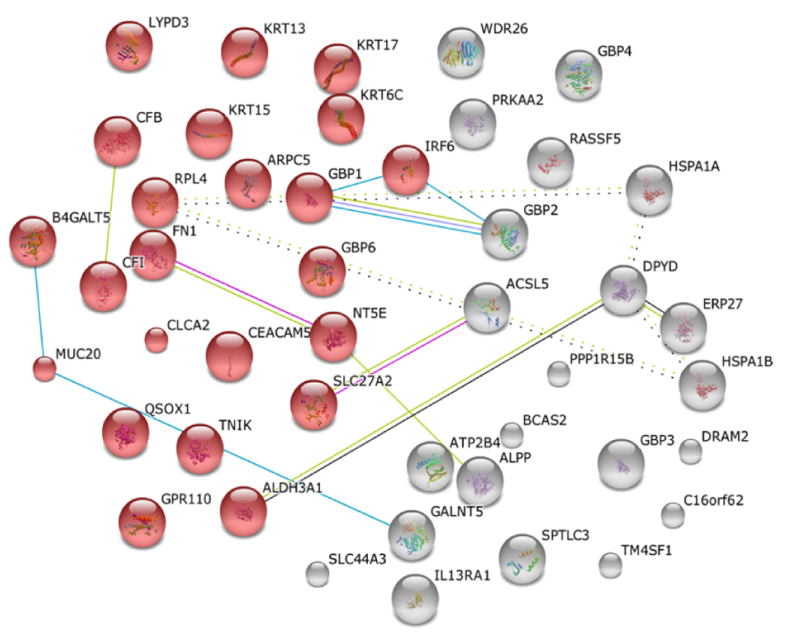

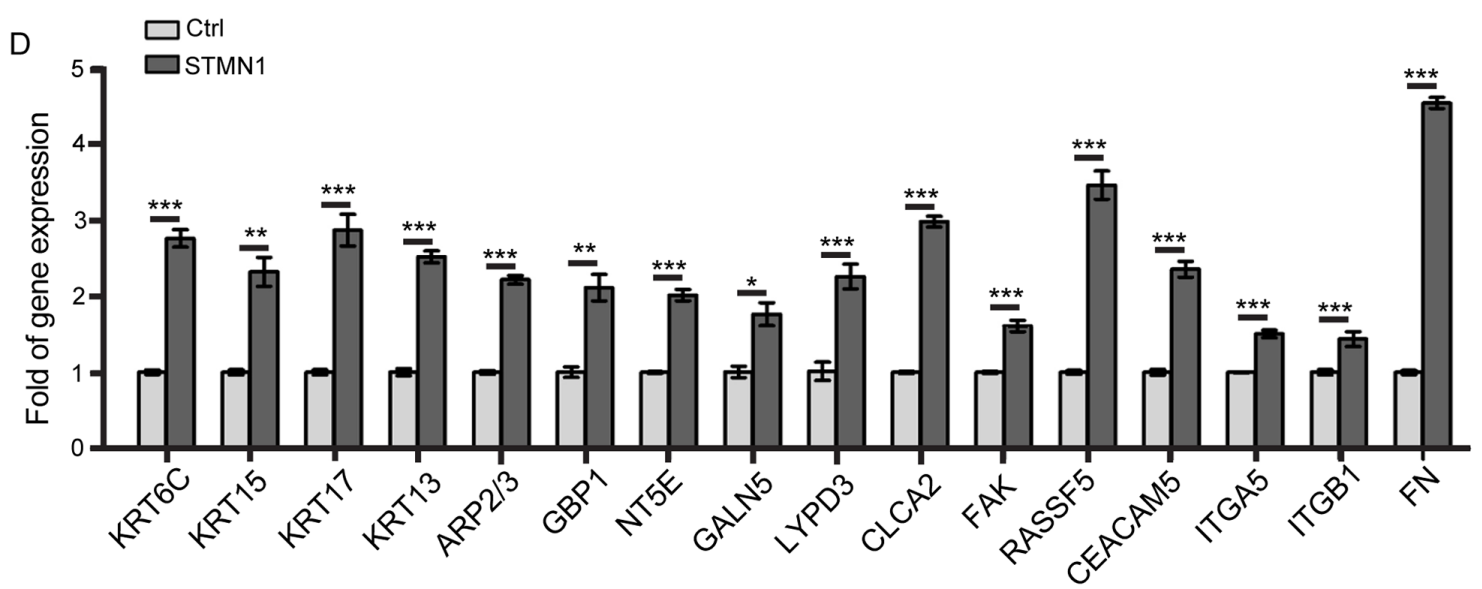

Figure 3: Gene expression changes in stathmin-overexpressing ESCC cells. (A) Heatmap representation of 90 genes showing significant differential expression between the STMN1 group and the control group. A color scale for the normalized expression data is shown on the right side of the microarray heatmap (green represents downregulated genes, whereas red represents upregulated genes). (B) The gene changes were functionally analyzed using the online tool STRING. (C) The upregulated genes were functionally classified based on their cellular components using the DAVID functional annotation clustering tool. (D) The mRNA levels of candidate genes were determined using real-time PCR. The data represent the mean \pm SD of relative mRNA levels versus control cells. $\left({ }^{*}, P<0.05 ; * *, P<0.01\right.$; $* * *, P<0.001)$. 
KRT17 and GBP1 genes were also tested for protein expression by western blot in the STMN1 and control group cells. The protein levels of the KRT17 and GBP1 genes were increased in the cells with stathmin overexpression (Figure 4G). These findings suggested that stathmin overexpression might affect cell adhesion and intermediate filaments by increasing the number of cellular adhesion molecules. Cytokeratin 17 (KRT17) is a basal cell keratin involved in the development and metastasis in ESCC of the esophagus [23, 24]. We investigated the stability of Keratin 17 via immune fluorescence staining in stathmin-overexpressing KYSE170 cells. After treatment with 2\% FBS medium for $6 \mathrm{~h}$, the intermediate filaments of the cells with stathmin overexpression maintained their shape, bearing tension and retaining rigidity; however, most of those of the control cells shrank and disintegrated (Supplementary Figure $3 \mathrm{~A}$ and $3 \mathrm{~B}$ ). In addition, knockdown of KRT17 decreased cell mobility in KYSE 170-STMN1 cells (Supplementary Figure 4A-4C). These results suggest that stathmin overexpression enhances the stability of intermediate filaments in the starvation.
A

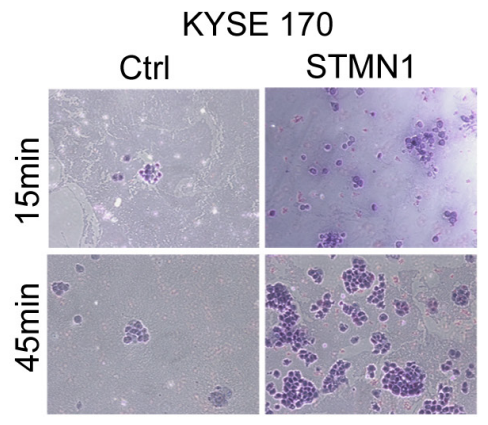

C

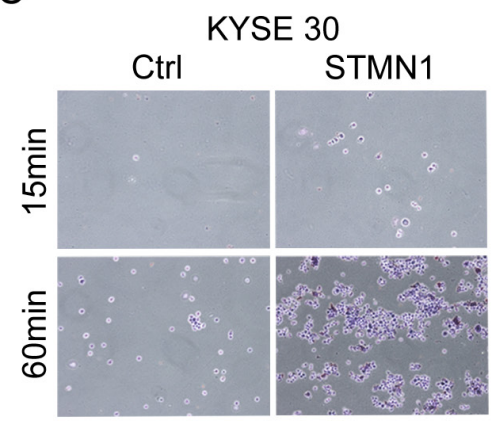

$E$

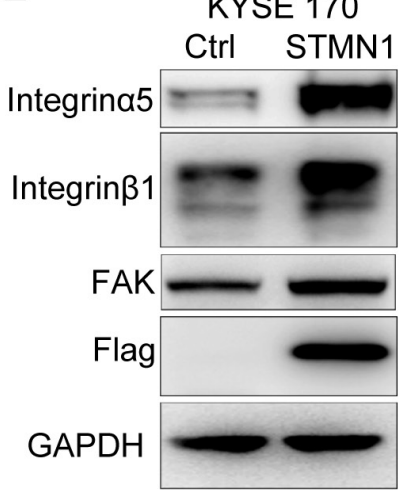

F
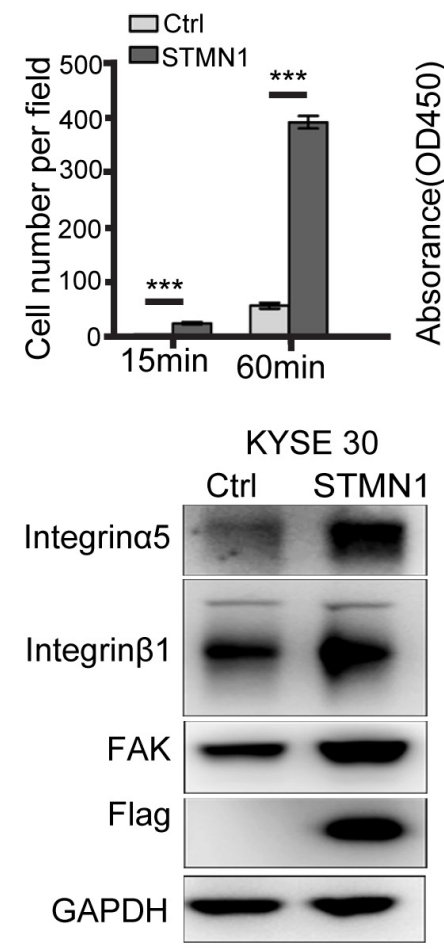

B
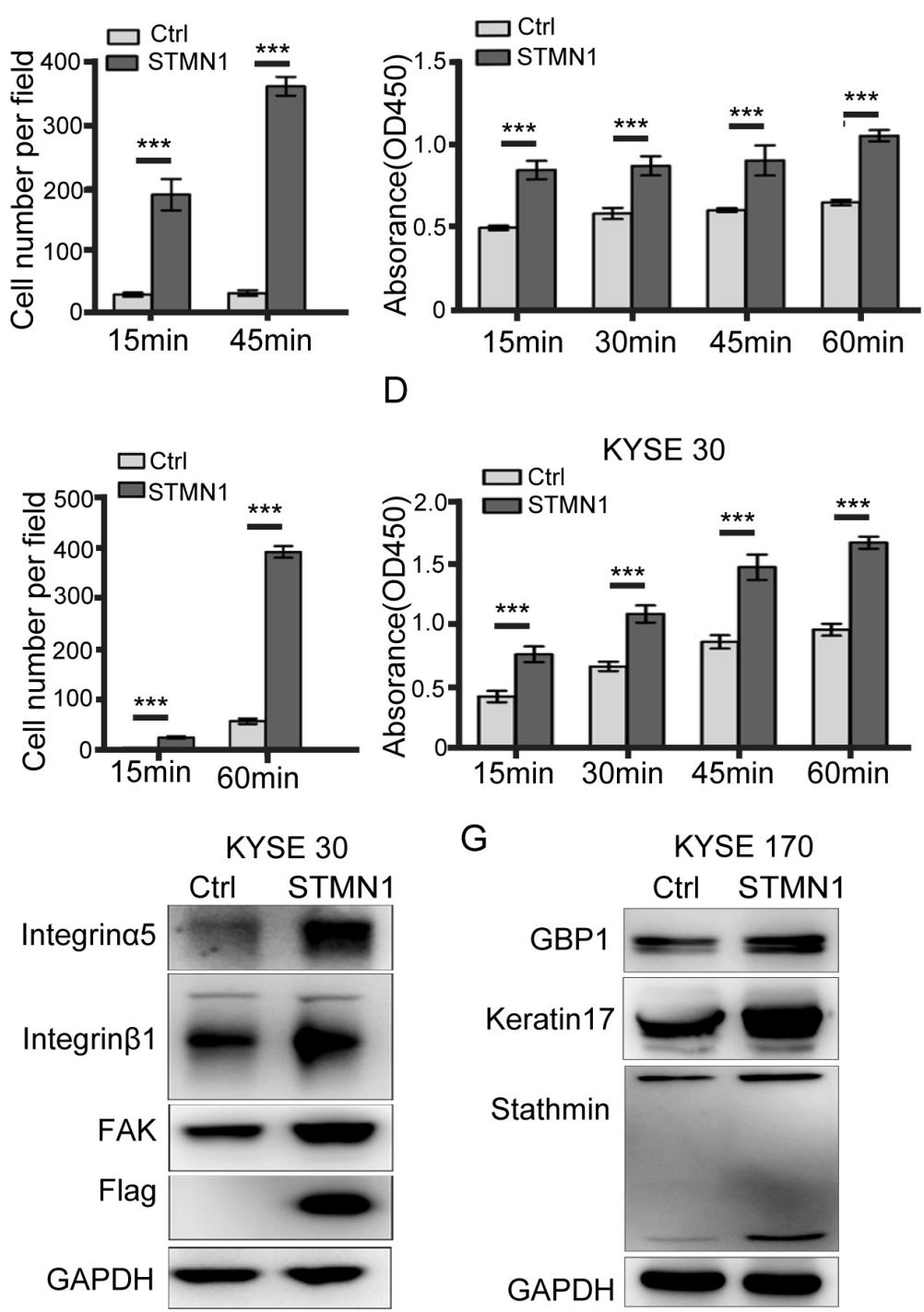

Figure 4: Stathmin increased ESCC cell adhesion to FN by promoting integrina5ß1/FAK expression. (A, C) Adhesion experiments showed that the level of cell adhesion to the FN-coated slides was significantly increased in the STMN1 group compared with that in the control group. (B, D) Adhesion experiments using FN-coated 96-well plates showed that the absorbance value of the STMN1 group was significantly higher than that of the control group. (E, F) The protein levels of integrin $\alpha 5 \beta 1$ and FAK were much higher in the STMN1 group than in the control group. (G) Immunoblotting identified differential keratin17 and GBP1 protein expression between theSTMN1 group and Ctrl group (***, $P<0.001)$. 


\section{Stathmin overexpression enhances cell adhesion and the integrin $\alpha 5 \beta 1 /$ FAK signaling pathway}

The transcriptome data showed that fibronectin (FN) and adhesion-related molecules were significantly increased in the STMN1 group. To evaluate cell adhesion ability, FN adhesion experiments were performed in cells with stathmin overexpression. As shown in Figure 4A and $4 \mathrm{C}$, cell attachment was time dependent. The levels of cell adhesion and absorbance were significantly increased in the cells with stathmin overexpression (Figure 4B and 4D). In contrast, knockdown of STMN1 led to decreased cell adhesion in KYSE 510 cells (Supplementary Figure $5 \mathrm{~A})$. These data indicated that stathmin overexpression facilitated cell adhesion in ESCC cells. Integrin $\alpha 5 \beta 1$ is the primary cell surface receptor for FN $[25,26]$, and integrin and focal adhesion kinase (FAK) are involved in cell adhesion and migration [27-29]. To address the contribution of the enhanced cell adhesion, we analyzed protein expression of the integrin family and FAK by western blotting in the STMN1 and control groups. As shown in Figure 4E and 4F, the total amounts of integrin $\alpha 5 \beta 1$ and FAK were significantly increased in stathmin-overexpressing KYSE170 and KYSE 30 cells. However, the integrin $\beta 3$, 4, and 5 and vinculin and p-vinculin levels did not significantly differ between the STMN1 group and the control group (Supplementary Figure 6A). Following knockdown of stathmin by siRNA, the protein levels of integrin $\alpha 5 \beta 1$ and FAK were greatly reduced in the KYSE 510 and KYSE 170-STMN1 cells (Figure 8E and $8 \mathrm{~F}$ ). These results demonstrate that stathmin increases the protein expression of integrin $\alpha 5 \beta 1$ and FAK.

To further evaluate the potential contribution of the integrin $\alpha 5 \beta 1 /$ FAK pathway in stathmin-overexpressing cells, we performed wound-healing and transwell assays after FAK knockdown by siRNA in KYSE 170-STMN1 cells. The western blotting results, shown in Figure $5 \mathrm{~A}$, revealed that FAK was strongly knocked down in KYSE 170-STMN1 cells. The motility and population of invasion cells were significantly reduced compared with those of the NC group (Figure 5B and 5C). In addition, cell adhesion was mitigated at a different time point from that of the NC group (Figure 5D). In KYSE 170-STMN1 cells treated with integrin $\alpha 5$ antibody, attenuated cell attachment was observed compared with cell attachment in the control group, as shown in Figure 5E. These data indicate that stathmin overexpression may increase cell adhesion and migration through the integrin $\alpha 5 \beta 1 / F A K$ signaling pathway in KYSE 170-STMN1 cells.
A

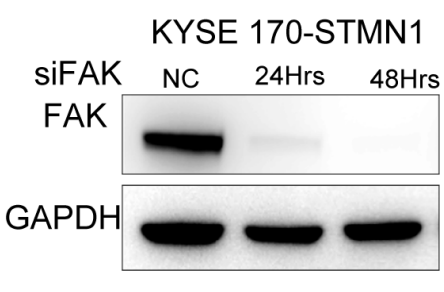

C

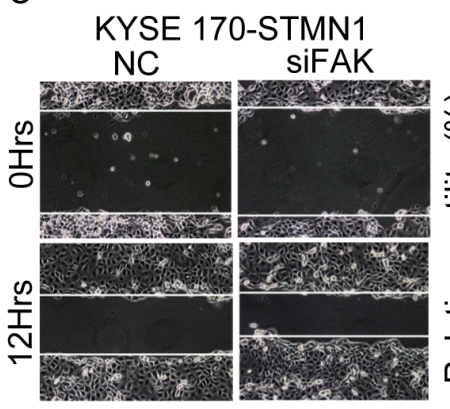

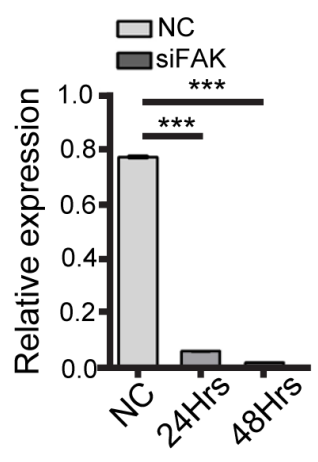

D

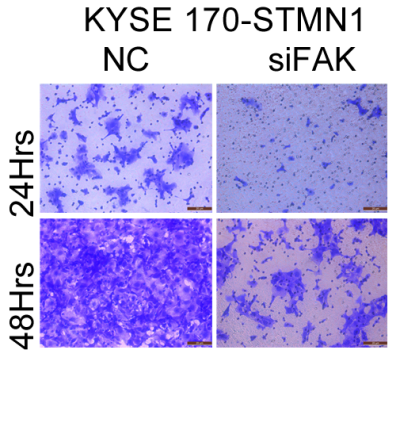

E

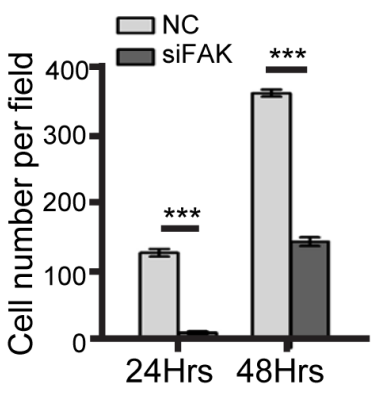

KYSE 170-STMN1
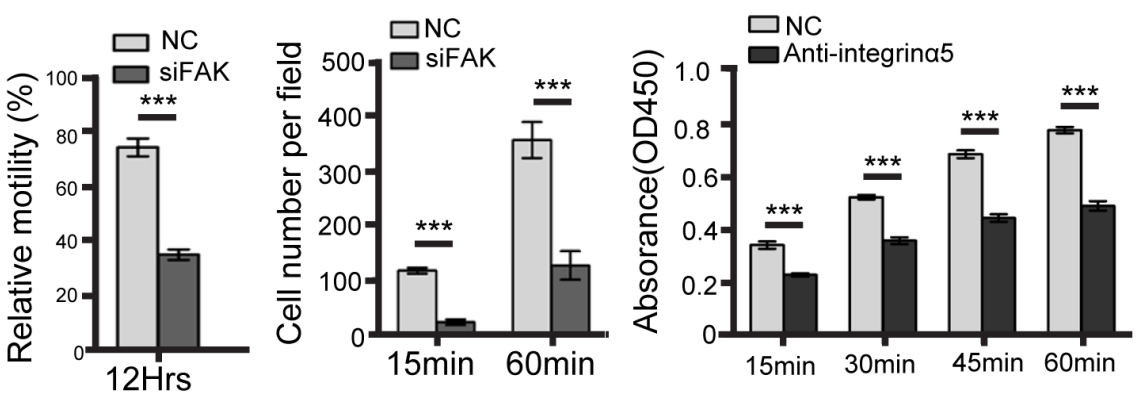

Figure 5: FAK knockdown inhibited metastasis of stathmin-overexpressing cells. (A) Western blotting showed that FAKspecific siRNA decreased FAK expression. (B) The transwell assay revealed that the invasion number of the FAK-knockdown group was significantly decreased compared with that of the NC group. (C) The wound-healing assay was performed to detect the migratory potential of FAK-knockdown KYSE 170-STMN1 cells and showed that the motility of the FAK-knockdown group was decreased compared with that of the NC group. (D) The cell adhesion assay to investigate cell adhesion ability showed that the level of cell adhesion to FN was lower in the FAK-knockdown group than in the NC group. (E) Cells were incubated with $10 \mathrm{ug} / \mathrm{ml}$ antibody against integrin $\alpha 545 \mathrm{~min}$ before plating on FN. Histograms represent the absorbance (OD450) $(* * *, P<0.001)$. 


\section{Stathmin overexpression increases lung metastasis and xenografted tumor growth in vivo}

To confirm the effect of stathmin overexpression on metastasis, we established a nude mouse model of metastasis in vivo to observe the lung metastasis ratio. STMN1 or control cells were injected into the tail vein of individual mice. After 39 days, three mice were euthanized. Two of the three STMN1-injected mice had developed metastatic nodules in the lung, whereas no metastasis was observed in the control group. After 49 days, all three mice in the STMN1 group had developed lung metastatic nodules, and two of the three mice injected with control cells had also developed metastatic nodules (Figure 6B). HE staining of the mouse lung tissue revealed that the size of the nodules in the STMN1 group was much larger than that of the control group (Figure 6C and $6 \mathrm{D}$ ). Furthermore, mouse body weight was reduced in the KYSE170-STMN1 metastasis model relative to the control group $(P<0.001)$ (Figure 6A). To investigate the tumor growth of stathmin-overexpressing cells in vivo, we evaluated tumor volume and weight in a mouse xenograft model. Mice bearing KYSE 170-STMN1 and control cells were inoculated for five weeks by subcutaneous injection, and no significant difference in body weight between the two groups were observed (Figure 7B). However, tumor volume and weight were greatly increased in the stathminoverexpression group compared to those in the control group (Figure 7A and 7C). Tumors from STMN1 and control models were examined for markers of tumor cell proliferation (Ki67), keratin 17 and stathmin. As shown in Figure 7D, significant increases in stathmin, Ki67 and keratin 17 in tumor tissues were observed in the STMN1 group. These data indicated that stathmin overexpression promoted ESCC cell growth and metastasis in the mouse in vivo model.
A

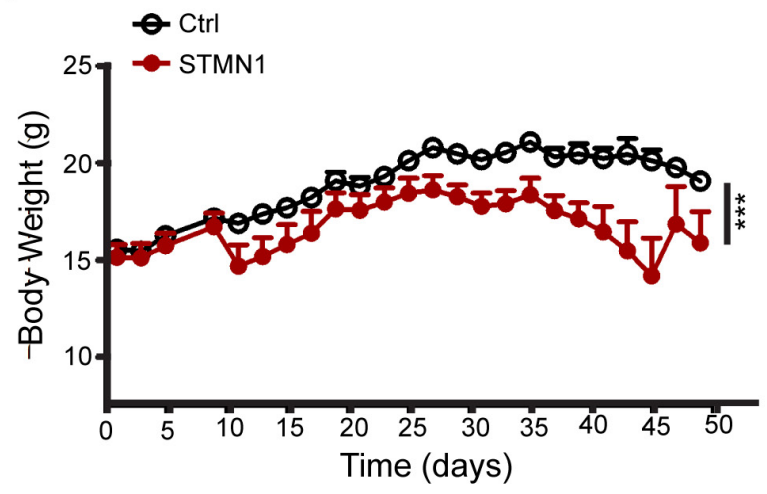

C

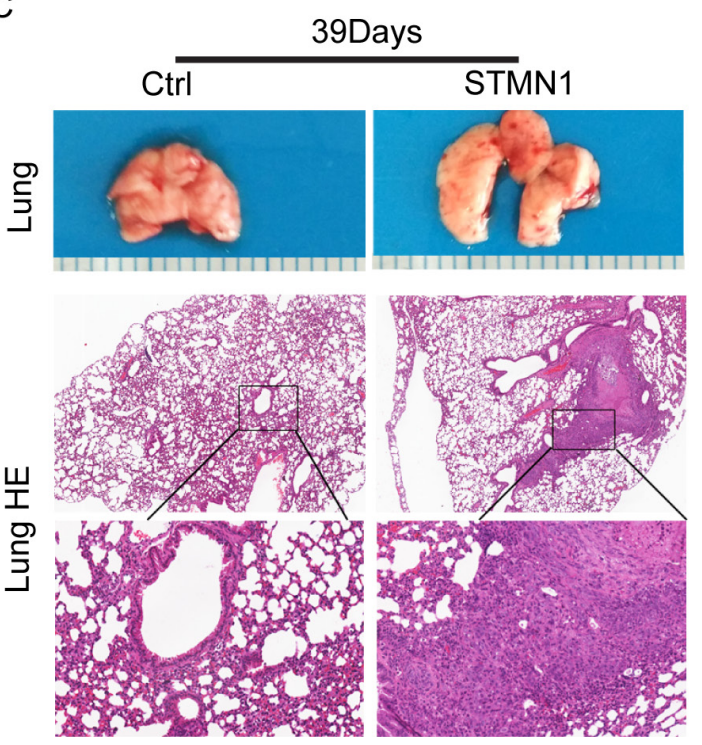

B

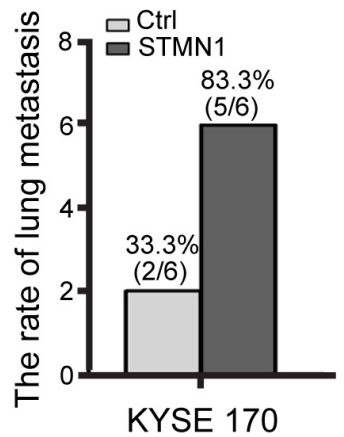

D

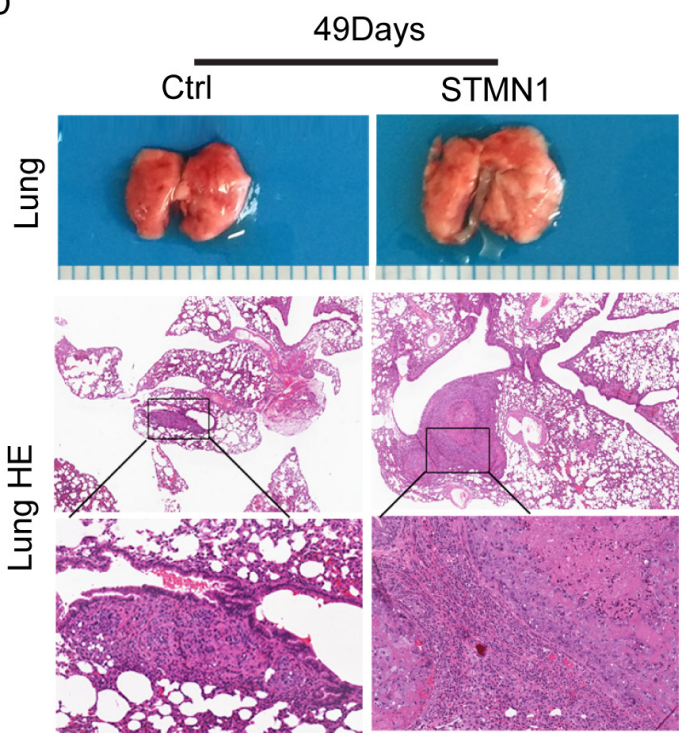

Figure 6: Stathmin overexpression increased ESCC cell lung metastasis in vivo. (A) ESCC cells were implanted into mouse tail veins, and body weight was measured every two days. Body weight was significantly lower in mice injected with STMN1 cells than in the control group $(P<0.001)$. (B) Statistical results of lung metastasis. (C) After 39 days, the STMN1 cell-injected mice had developed metastatic nodules, whereas the control group had not. (D) After 49 days, both groups of ESCC cell-injected mice developed metastatic nodules, although the lung metastasis area was larger in the STMN1-injected mice. 


\section{Stathmin regulates ERK activation}

As described above, stathmin overexpression promoted integrin $\alpha 5 \beta 1 /$ FAK expression and contributed to ESCC cell adhesion and migration in vitro and in vivo. To identify whether stathmin can affect the kinase activity of FAK downstream, we analyzed the phosphorylation levels of ERK, JNK, AKT, and mTOR by performing western blotting. The protein and phosphorylation levels of AKT, JNK and mTOR did not significantly differ between the STMN1 group and the control group (Supplementary Figure 5A-5C). In contrast, the P-ERK level was significantly increased in the STMN1 group compared to that in the control group. The total level of ERK did not differ between the two groups (Figure 8A). Real-time PCR analysis confirmed that the mRNA level of ERK downstream transcription factors, including FOS, EGR1 and JUN, were increased in the STMN1-group cells (Figure 8B). Knockdown of stathmin in KYSE 510 and KYSE 170-STMN1 cells resulted in a significant decrease of P-ERK levels (Figure 8E and 8F). To determine whether the ERK pathway activation was related to cell migration in the STMN1 group, we used the ERK phosphorylation inhibitor AZD8330 to treat the KYSE 170-STMN1 cells. The P-ERK levels were decreased after treatment with AZD8330 for $3 \mathrm{~h}$. The in vitro wound-healing assay showed that the motility of the KYSE 170-STMN1 cells treated with AZD8330 was inhibited compared with that of the DMSO group (Figure 8C and 8D). Following knockdown of stathmin by siRNA, the protein levels of integrin $\alpha 5 \beta 1$, FAK and P-ERK were greatly reduced in the KYSE 510 and KYSE 170-STMN1 cells (Figure 8E and 8F). As illustrated in Figure 9, we propose a model to explain how stathmin overexpression promotes metastasis in ESCC cells: (i) the overexpression of stathmin increases the number cellular adhesion molecules and (ii) increases the keratin 17 of intermediate filaments for metastasis, (iii) promoting cell invasion and migration via the $\mathrm{FN} /$ integrin $\alpha 5 \beta 1 / F A K$ signaling pathway. The results indicate that stathmin overexpression influences ESCC cell invasion and migration via the integrin $\alpha 5 \beta 1 / F A K / E R K$ signaling pathway.
A

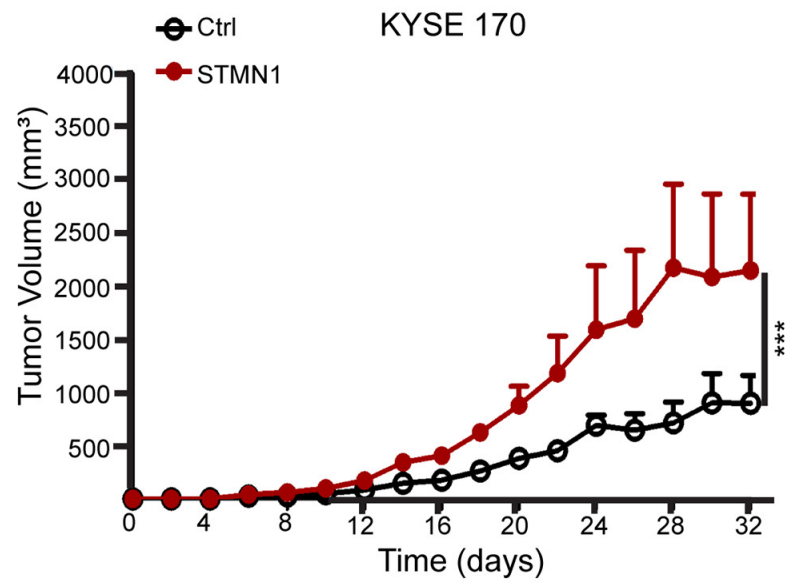

B

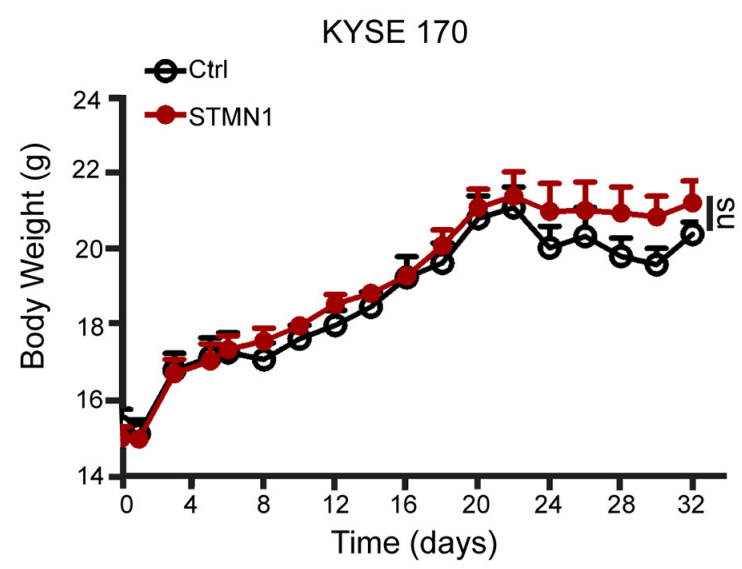

C

D
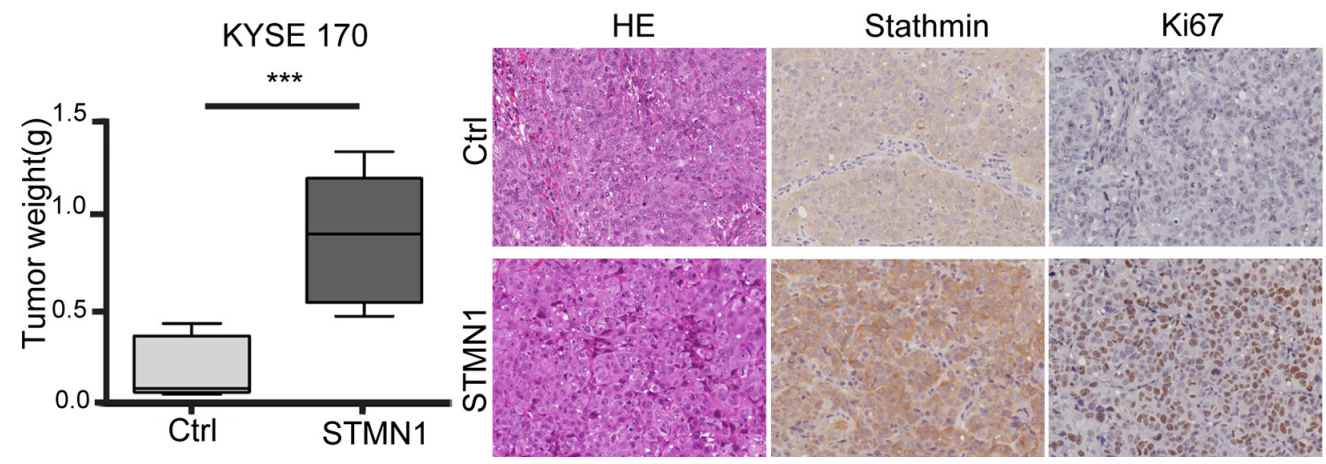

Keratin17

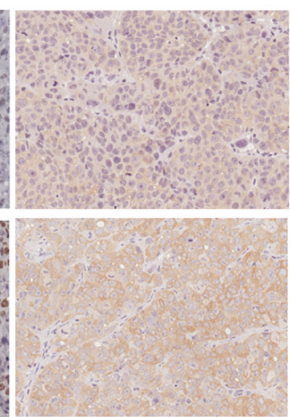

Figure 7: Stathmin overexpression increased xenografted tumor growth. (A, C) Control cells and STMN1 cells were orthotopically inoculated into nude mice. Tumor volume and tumor weight significantly increased in mice injected with STMN1 group compared with the control group. (B) Body weight was measured every two days after injection, and no significant difference was observed between the two groups. (D) IHC staining showed strong staining in the tissue sections for stathmin, Ki67 and keratin 17 in the STMN1 group. 


\section{DISCUSSION}

Currently, the sensitivity and diagnostic value of serum markers for ESCC are low [6, 30-32]. In a previous study, our laboratory found that stathmin expression was significantly upregulated in ESCC, which might act as a biomarker for ESCC diagnosis and prognosis [21]. To investigate the levels of serum stathmin, we evaluated 535 ESCC patients and 288 healthy controls by ELISA. The results showed that the level of serum stathmin
A

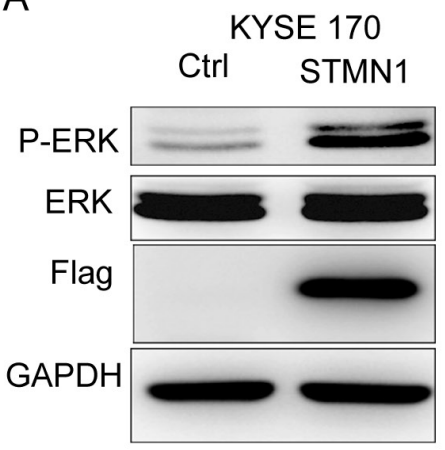

C

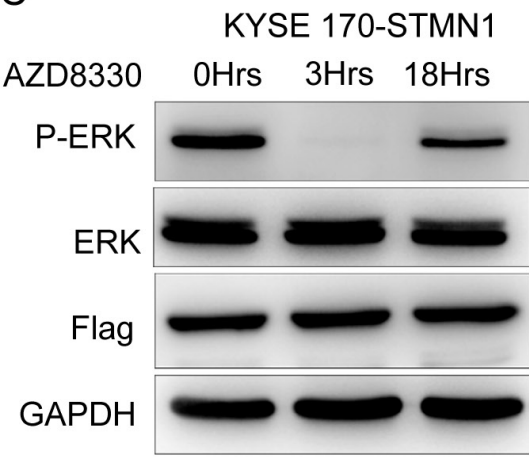

E

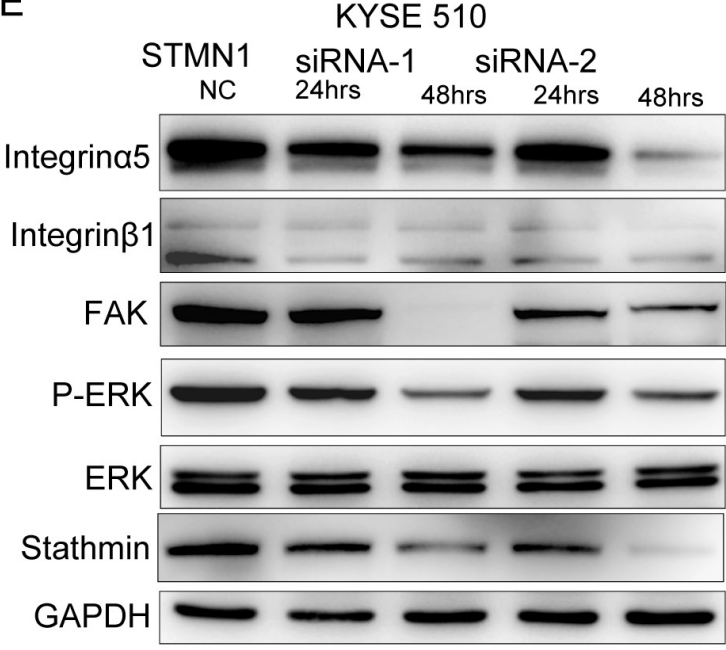

D
B
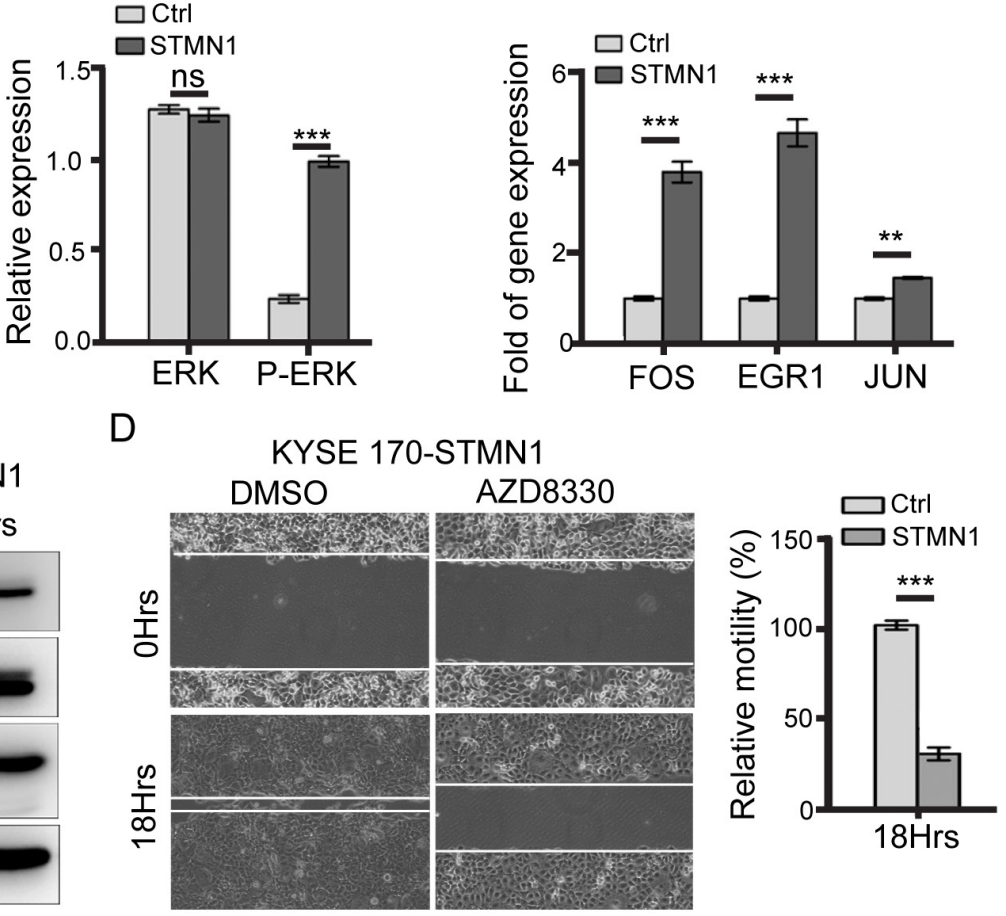

$\mathrm{F}$
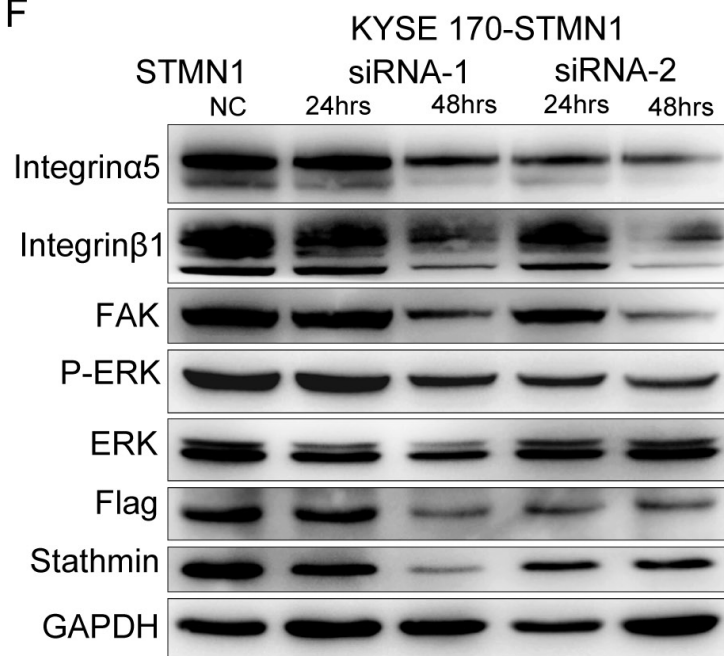

Figure 8: Stathmin regulated ERK activation. (A) Western blot analysis showed that the protein level of P-ERK in the STMN1 group was significantly higher than that of the control group. (B) RT-PCR analysis of the mRNA levels of ERK downstream transcription factors such as FOS, EGR1, and JUN revealed significantly higher levels in the STMN1group than in the control group. (C) KYSE 170-STMN1 cells were treated with ERK inhibitors AZD8330; western blot analysis showed that ERK phosphorylation was inhibited. (D) The effects of ERK phosphorylation on the migration ability of KYSE 170-STMN1 cells were analyzed by woundhealing assay. The results showed that inhibition of ERK phosphorylation in KYSE 170-STMN1 cells markedly reduced cell motility. (E) Stathmin expression in KYSE 510 and (F) KYSE 170-STMN1 cells was knocked down by two different STMN1-specific siRNAs (siRNA-1 and siRNA-2), and the activation of the integrin $\alpha 5 \beta 1 /$ FAK/ERK pathway was measured by immunoblotting (ns, $P>0.05$; *, $P<0.05$; ***, $P<0.001)$. 
in ESCC patients was significantly higher than that in healthy controls $(5.98 \pm 2.89 \mathrm{ng} / \mathrm{ml}$ vs. $2.16 \pm 1.19 \mathrm{ng} / \mathrm{ml}$, $P<0.001$ ), which indicated that high levels of stathmin may be particularly related to the malignant behavior of ESCC. We also observed that high levels of stathmin were positively correlated with lymph node metastasis, advanced TNM stage and tumor size in ESCC. These results suggested that stathmin has the potential to be a diagnostic marker for ESCC. Our findings are consistent with those of previous investigations reporting that overexpression of stathmin in ESCC tissue was associated with poor prognosis [19-22]. We found that stathmin acts as a marker for ESCC diagnosis with a sensitivity of 0.886 , a specificity of 0.806 , and a serum cutoff value of 3.014 $\mathrm{ng} / \mathrm{ml}$. Thus, overexpression of stathmin might promote oncogenesis and the development of ESCC, followed by cell motility, proliferation and metastasis of ESCC.

The in vitro experiments confirmed that overexpression of stathmin promotes ESCC cell proliferation, adhesion and metastasis; and the xenograft experiments demonstrated that stathmin overexpression increased mouse tumor burden and promoted lung metastasis of ESCC cells. Stathmin overexpression enhanced ESCC cell adhesion to the extracellular matrix by promoting the expression of integrin $\alpha 5 \beta 1 / \mathrm{FAK}$. In addition, integrin $\alpha 5 \beta 1 / \mathrm{FAK}$ expression increased activation of the ERK pathway, promoted adhesion-related gene expression, and enhanced the migration of ESCC cells. These results support the notion that stathmin has a vital role in ESCC progression. Significantly elevated levels of stathmin have been detected in the urine and blood from urothelial carcinomas of the bladder using ELISA [33]. Mass spectrometry analysis of protein extracted from lung cancer cell culture medium revealed high levels of stathmin, which suggests that stathmin is released from lung cancer cells in some channels. Stathmin can be detected in ExoCarta, suggesting that it can be secreted from the cells [34]. Stathmin can be detected in the serum by ELISA, and serum stathmin protein levels were significantly elevated in ESCC patients and associated with lymph node metastasis and other clinical parameters. These results suggest that stathmin can be used as a serum biomarker for ESCC detection.

Cell movement contributes to cell membrane contraction, which depends on cell-extracellular matrix adhesion and dissociation. The cytoskeleton mainly consists of microfilaments, microtubules and intermediate fibers and regulates cell motility, cell cycle, intracellular signal transduction and other important biological processes. Stathmin plays an important role in the regulation of cytoskeleton dynamics. One stathmin protein can bind with two $\alpha, \beta$-heterodimers to form a $\mathrm{T}_{2} \mathrm{~S}$

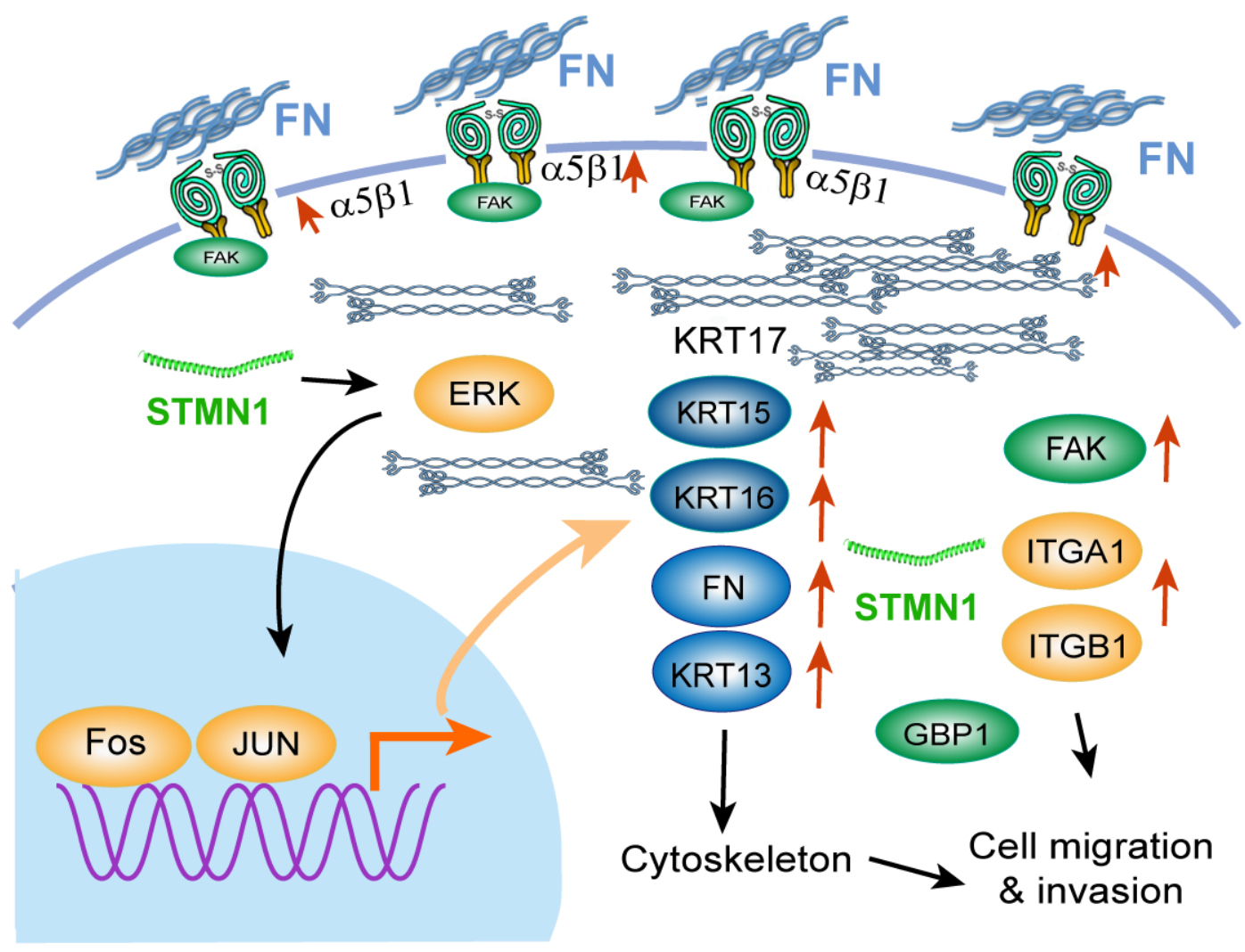

Figure 9: Illustration of the signaling pathway for ESCC cell migration induced by stathmin overexpression. Overexpression of stathmin increased the number of cellular adhesion molecules and the level cytokeratin 17 of intermediate filaments, promoting cell invasion and migration via the FN/integrin $\alpha 5 \beta 1 /$ FAK signaling pathway. The red arrows indicate the upregulated genes. 
Table 2: Primers for qRT-PCR

\begin{tabular}{|c|c|}
\hline GENE name & \\
\hline KRT6C & Forward 5' -GGATGCTTAGTGCCCTCACTT-3' \\
\hline & Reverse 5' -GCTCAGCCTCAGAGAGAACAAT- 3' \\
\hline KRT15 & Forward 5' -GGATGCTTAGTGCCCTCACTT-3' \\
\hline & Reverse 5' -GCTCAGCCTCAGAGAGAACAAT-3' \\
\hline KRT17 & Forward 5'-GCTCAGCATGAAAGCATCCC-3' \\
\hline & Reverse 5' -TTGTACTGAGTCAGGTGGGC-3' \\
\hline KRT13 & Forward 5' -GCTCAGCATGAAAGCATCCC-3' \\
\hline & Reverse 5' -TTGTACTGAGTCAGGTGGGC-3' \\
\hline $\mathrm{ARP} 2 / 3$ & Forward 5' -GCGGCAAGGAAACATGACAG- 3' \\
\hline & Reverse 5' -CAGACGGGCTCTCAAATCCTT-3' \\
\hline GBP1 & Forward 5' -AGCCCTACAACTTCGGAACAG- 3' \\
\hline & Reverse 5' -TCTGGATTCGCCATCAGTCG- 3' \\
\hline NT5E & Forward 5' -GTATCCGGTCGCCCATTGAT-3' \\
\hline & Reverse 5' -AAAGGCCTTCTTCAGGGTGG-3' \\
\hline GALNT5 & Forward 5' -AGCCCCGGAAGAGTCATAG-3' \\
\hline & Reverse 5' -GTGCCCTCTCGTTTGCTACT-3' \\
\hline FN & Forward 5' - ACAAGCATGTCTCTCTGCCAA-3' \\
\hline & Reverse 5' -GCAATGTGCAGCCCTCATTT-3' \\
\hline LYPD3 & Forward 5' -CACGGACAATTCTCGCTGG- 3' \\
\hline & Reverse 5' -GCGGGTATGCACTCTCATTAC- 3' \\
\hline CLCA2 & Forward 5' -AAAGTGACAGTGACCTCTCGC-3' \\
\hline & Reverse 5' -GGCAGTGACAGTGGCATTAAG- 3' \\
\hline FAK & Forward 5' - AGCCGTTCGGGATTTTGCTA-3' \\
\hline & Reverse 5' -TGTTGGGATGGTCGAACTGG-3' \\
\hline RASSF5 & Forward 5'-AGTAGCGCAGTCGCCAAA- 3' \\
\hline & Reverse 5' -GTCCAATAGTAGCGGGTACGG- 3' \\
\hline CEACAM5 & Forward 5' -CTGTCCAATGACAACAGGACC- ${ }^{\prime}$ ' \\
\hline & Reverse 5' -ACGGTAATAGGTGTATGAGGGG-3' \\
\hline ITGA5 & Forward 5' -TTACGGGACTCAACTGCACC-3' \\
\hline & Reverse 5' -AGCCTGAAACACTCAGCCTC- 3' \\
\hline ITGB1 & Forward 5' -CCTACTTCTGCACGATGTGATG- ${ }^{\prime}$ ' \\
\hline & Reverse 5' -TCCCCTGATCTTAATCGCAAAAC- 3' \\
\hline EGR1 & Forward 5' -TCGAGTTGGCAAAATGGGGT-3' \\
\hline & Reverse 5' -TCACCATTGGTTTGCTTGGC-3' \\
\hline FOS & Forward 5' -ATGGACCAGTGAAGCGATCAT-3' \\
\hline & Reverse 5' -GTTCCTCCAAACTAGAAGCAGC-3' \\
\hline JUN & Forward 5' -ACACGGCTTCGAGTCACTG- 3' \\
\hline & Reverse 5'-CGTCCTGGAAACCGTCCTTC-3' \\
\hline
\end{tabular}


complex and promotes $\alpha, \beta$-heterodimer dissociation from the microtubule. Otherwise, stathmin binds to the free microtubule heterodimers, which inhibits their assembly to the microtubule tip $[8,9]$. In neuroblastoma cells, changes in the level of stathmin expression regulate the level of activation of the RhoA/ROCK pathway and consequently modulate changes in microfilaments $[35,36]$. In this study, we found that the mRNA levels of KRT17, KRT15 and KRT13 and the protein level of KRT17 in stathminoverexpressing cells were significantly increased, suggesting that stathmin affects the levels of intermediate filament family members. These results indicate that stathmin affects not only the microtubule dynamics but also the entire cytoskeleton.

The in vitro experiments showed that stathmin promoted ESCC cell metastasis. To characterize the molecular pathways affected by stathmin in ESCC cells, we used the Human Transcriptome Array (HTA2.0) to perform microarray-based global gene expression profiling of cancer cells with exogenous forced stathmin levels. We found that the mRNA levels of adhesion-related molecules and FN were significantly increased in the STMN1 group, which suggest that stathmin may exert a strong impact on cell-extracellular matrix adhesion. To test this hypothesis, slides were coated with FN, which is the main component of the extracellular matrix, to evaluate cellextracellular matrix adhesion ability. The results showed that adhesion capacity was significantly increased in the STMN1 group. Integrins, the main family of cell surface receptors, mediate cell-extracellular matrix adhesion and signal transduction [37-39]. Integrin $\alpha 5 \beta 1$ recognizes the extracellular matrix tripeptide (Arg-Gly-Asp, RGD) of FN. The extracellular receptors of integrin $\alpha 5 \beta 1$ are inhibited by specific inhibitors, which can reduce the angiogenesis and tumor cell metastasis of colon cancer [40-42]. FAK has two different functions: to serve as a scaffold protein to recruit other proteins and mediate their protein-protein interactions and to act as a protein kinase to phosphorylate downstream substrates. FAK, which acts as a scaffolding protein, plays an important role in promoting tumor growth and metastasis in anaplastic thyroid cancer [43]. The intracellular domain of integrins can recruit FAK and FAK coupled with the cytoskeleton to form stable focal adhesions [44, 45]. Treatment with lunasin (an Arg-Gly-Asp, (RGD) cancer suppressor polypeptide) inhibits the activation of the FAK/ERK/NF- $\kappa B$ pathway in integrin $\alpha 5 \beta 1$-overexpressing cells, inhibiting the invasion and metastasis of colon cancer. However, it is insensitive to cells with low integrin $\alpha 5 \beta 1$ expression $[41,46]$. Enhance cell and extracellular matrix crosstalk, which can promote integrin clustering and elevate the expression of FAK, contributes to cell adhesion, proliferation and invasion [47]. In this study, we found that stathmin promotes invasion, metastasis and adhesion of ESCC cells, and we found that integrin $\alpha 5 \beta 1 / F A K$ protein levels were increased in STMN1 group. Silencing of FAK by specific siRNA significantly suppressed the adhesion, invasion and migration of KYSE 170-STMN1 cells. This finding suggests that extent to which stathmin promotes metastasis depends on the extent of integrin $\alpha 5 \beta 1 / F A K$ pathway activity increase in ESCC cells. In addition, the protein levels of integrin $\alpha 5 \beta 1 / \mathrm{FAK}$ in stathmin-silenced cells were decreased, further demonstrating that the activation of the integrin $\alpha 5 \beta 1 / F A K$ pathway was affected by the level of stathmin protein.

The ERK pathway is a relatively mature pathway that regulates the expression of genes, cell proliferation, migration and other activities [48, 49]. The expression of $\mathrm{FN}$ is positively correlated with the invasion and metastasis of ESCC, which may be related to the activation of the ERK pathway $[50,51]$. The levels of the ERK downstream transcription factors FOS, JUN, EGR1 were significantly increased in the STMN1 group, which indicated that the overexpression of stathmin increased activation of the ERK pathway. Integrin/FAK activates the Ras/ERK pathway, mediates cell-extracellular matrix adhesion and promotes cell proliferation [51-53].

In summary, this study demonstrated that STMN overexpression increased the number of cellular adhesion molecules and facilitated ESCC cell invasion and migration via the $\mathrm{FN} /$ integrin $\alpha 5 \beta 1 / \mathrm{FAK}$ signaling pathway by increasing the amount of cytokeratin 17 .

\section{MATERIALS AND METHODS}

40, 6-diamidino-2-phenylindole (DAPI) was obtained from Sigma-Aldrich (St. Louis, MO).Stathmin, FAK, integrin $\alpha / \beta 1$, Akt, phospho-Akt, ERK, phosphoERK, phospho-S6, 4EBP1, phospho-4EBP1, FLAG, keratin17,JNK, and phospho-JNK antibodies were purchased from Cell Signaling Technology (Boston, MA). The anti-human CD49e integrin $\alpha 5$ blocking antibody was purchased from Biolegend (San Diego, CA). FAK inhibitor (PF-00562271), ERK inhibitor (AZD8330) and mitomycin $\mathrm{C}$ were purchased from Selleck Chemicals (Houston, TX). RPMI-1640 and Opti-MEM medium were purchased from Gibco-BRL (Grand Island, NY). Fetal bovine serum (FBS) was purchased from PAA (Pasching, Austria), and Lipofectamine 2000 was purchased from Invitrogen (Carslbad, CA).

\section{ELISA assay}

Serum samples of pathology-confirmed esophageal squamous cell carcinoma were obtained from patients at the Cancer Hospital of Chinese Academy of Medical. In addition, serum from 120 patients with other cancers, comprising 30 hepatocellular carcinoma (HCC) patients, 30 colorectal cancer (CRC) patients, 30 gastric cancer (GC) patients and 30 head and neck cancer (HNC) patients were collected from the same hospital. Serum samples from healthy controls were collected from the Beijing 
Coal General Hospital of the health examination center. The ELISA kit was purchased from the US (Cloud-Clone company, No. SE-C892Hu). Serum samples and standards were diluted, added to the wells, and incubated at $37^{\circ} \mathrm{C}$ for $2 \mathrm{~h}$. The liquid in the plate was removed, and $100 \mu \mathrm{l}$ of working solution A was added to each well. The wells were then aspirated at $37^{\circ} \mathrm{C}$ for $1 \mathrm{~h}$ and washed 3 times. Then, $100 \mu \mathrm{l}$ of reaction solution $\mathrm{B}$ was added to each well, followed by incubation at $37^{\circ} \mathrm{C}$ for $30 \mathrm{~min}$. Then, the wells were washed 5 times, and $90 \mu$ of substrate solution was added to each well, followed by incubation at $37^{\circ} \mathrm{C}$ for $20 \mathrm{~min}$. Next, $50 \mu \mathrm{l}$ of stop solution was added to each well. The absorbance at $450 \mathrm{~nm}$ was read from a blue-to-yellow plate reader (Bio-rad) according to the concentration and A-value of the kit standard. The stathmin concentrations in the serum samples were measured and analyzed statistically based on sample A 450. Each sample was repeated 3 times; the mean value was taken as the serum stathmin concentration of the sample.

\section{Cell lines and cell culture}

The human ESCC cell lines KYSE 170, KYSE 30 and KYSE 510 were a generous gift from Dr. Y Shimada (Kyoto University, Japan). The cells were cultured in complete RPMI 1640 medium supplemented with 10\% FBS, penicillin $(100 \mathrm{U} / \mathrm{ml})$, and streptomycin $(100 \mathrm{mg} /$ $\mathrm{ml})$ at $37^{\circ} \mathrm{C}$ in a humidified incubator containing $5 \% \mathrm{CO}_{2}$.

\section{Plasmid DNA transfection}

Cell lines transfected with human STMN1 or empty vector pCMV6were established by transfection of pCMV6 vector (Origene) containing the full-length STMN1 cDNA or pCMV6 vector alone, respectively, into esophageal cancer cells KYSE 170 and KYSE 30 using Lipofectamine 2000 as per the manufacturer's instructions. The stable clones were selected with $200 \mathrm{ug} / \mathrm{ml} \mathrm{G} 418$.

\section{siRNA transfection}

Prior to transfection, cells were plated in 6-well plates and allowed to reach $80 \%$ confluence. After $12-$ $16 \mathrm{~h}$ of culture, $5 \mu \mathrm{l}$ of Lipofectamine 2000 and $5 \mu \mathrm{l}$ of duplexed siRNA (sequences:

si-FAK:5'-CCCAGGUUUACUGAACUUATT-3',

5'-UAAGUUCAGUAAACCUGGGTT-3'; si-STMN-1:5'-

UCGCUUGUCUUCUAUUCACTT-3',

5'-GUGAAUAGAAGACAAGCGATT-3'; si-STMN-2:5'-

CAAAGAAGAAGGAUCUUUCTT-3',

5'-GAAAGAUCCUUCUUCUUUGTT-3'; si-KRT17-2:5'-

CCCACCUGACUCAGUACAATT-3', 5'-UUGUACUGAGUCAGGUGGGTT-3'; and
si-KRT17-3:5'-

GCGUACCAUUGUGGAAGAGTT-3',

5'-CUCUUCCACAAUGGUACGCTT-3';

GenePharma, Shanghai, China) were separately pre-incubated in $150 \mu \mathrm{l}$ of Opti-MEM for $5 \mathrm{~min}$. These two solutions were then mixed and incubated at RT $30 \mathrm{~min}$. The cells were washed twice with $1 \times \mathrm{PBS}$ and preincubated in $700 \mu \mathrm{l}$ of Opti-MEM medium. The siRNA and liposome mixture was then added to the culture medium. After $6 \mathrm{~h}$, the medium was replaced with culture medium containing 10\% FBS. The cells were harvested after $48 \mathrm{~h}$, and knockdown efficiency was verified by Western blot analysis.

\section{Western blot analysis}

The total protein extracts from cells were prepared in ice-cold cell lysis buffer $(50 \mathrm{mM}$ Tris- $\mathrm{HCl}, \mathrm{pH} 8.0$, with $150 \mathrm{mM} \mathrm{NaCl}, 1.0 \% \mathrm{NP}-40,0.5 \%$ sodium deoxycholate, and $0.1 \%$ SDS) containing protease inhibitor $(500 \mathrm{mM}$ phenylmethylsulfonyl fluoride). The cell homogenate was spun at $12,000 \mathrm{rpm}$ for $15 \mathrm{~min}$ at $4^{\circ} \mathrm{C}$, and the protein concentration in the supernatant was determined by the Bradford assay. Approximately $30 \mu \mathrm{g}$ of the supernatant was resolved by SDS-PAGE and transferred onto Millipore polyvinylidene diffuoride membranes. The membranes were blocked for $3 \mathrm{~h}$ with $10 \%(\mathrm{w} / \mathrm{v})$ nonfat dry milk in $1 \times \mathrm{PBS}$ and incubated with primary antibodies diluted in $3 \%$ milk $1 \times$ PBS buffer at $4{ }^{\circ} \mathrm{C}$ overnight. After washing with Tris-buffered saline (TBS) containing $0.1 \%$ Tween-20 (TBS-T), the blots were incubated for $1 \mathrm{~h}$ at RT with goat anti-rabbit/mouse IgG horseradish peroxidaseconjugated secondary antibody (1:3,000 dilution) in 3\% milk $1 \times$ PBS buffer. The blots were again washed thrice with TBS-T for $15 \mathrm{~min}$ and then developed with ECL Western blotting detection reagent (GE Healthcare). All blots were reprobed for $\beta$-actin $(1: 3,000)$ or GAPDH $(1: 3,000)$ as an internal reference for protein loading. The band intensities of scanned blots were quantified using Image J. The integrated intensity of a fixed area was measured, and background levels were subtracted.

\section{Wound-healing assays}

Cell monolayer were scraped with a sterile pipette tip and cultured in RPMI-1640 supplemented with 10\% FBS. Wound closure was monitored for different times, and the cells were fixed and stained with Coomassie Brilliant Blue. The photographs represent one of three independent experiments $(10 \times$ magnification, phasecontrast microscopy).

\section{Transwell migration assays}

In vitro cells migration was measured in Transwell Chambers ( $5 \mu \mathrm{m}$; Corning Costar). Cells were seeded onto the upper chamber. Transmigrated cells were fixed 
and stained with crystal violet (AMRESCO). The cells were manually quantified by obtaining counts from five photos of random fields of the underlying membrane and calculating the mean number.

\section{Adhesion assay}

Cell adhesion assay was performed on FN-coated 96-well plates or glass cover slips in 6-well plates, respectively. Briefly, cells were seeded with serum-free medium in the plates, and the cells were incubated at $37^{\circ} \mathrm{C}$ for different times to determine the adhesion to FN. The plates were then carefully washed twice with $1 \times \mathrm{PBS}$ to remove non-adherent cells. Next, for the 96-well plates, fresh medium containing 10\% FBS and 10\% $\mu \mathrm{l}$ WST8 was added to each well. The plates were incubated for another $3 \mathrm{~h}$, and the relative numbers of attached cells were detected at $450 \mathrm{~nm}$ using an enzyme-linked immunosorbent assay (ELISA) reader. For the glass cover slips in 6-well plates, the attached cells were fixed and stained with crystal violet, and the irrelative numbers were manually quantified by obtaining counts from photographs and calculating the mean number.

\section{Colony formation assay}

Cells were trypsinized and seeded in six-well plates $(200,500$, or 1000 cells per well) and cultured in RPMI1640 supplemented with 10\% FBS. After 10 days, cells were fixed in $4 \%$ formaldehyde and stained with $0.25 \%$ crystal violet. Clones were washed and counted. All experiments were carried out in triplicate.

\section{Immunofluorescent staining}

Cells growing in the logarithmic phase were seeded onto glass cover slips overnight, fixed with $4 \%(\mathrm{w} / \mathrm{v})$ paraformaldehyde for $30 \mathrm{~min}$, and rinsed with $1 \times \mathrm{PBS}$ for $15 \mathrm{~min}$. The cells were subsequently permeabilized with $0.1 \%(\mathrm{w} / \mathrm{v})$ Triton $\mathrm{X}-100$ at RT for $10 \mathrm{~min}$, rinsed with $1 \times \mathrm{PBS}$, and incubated with $1 \times \mathrm{PBS}$ containing $2 \%$ BSA for $30 \mathrm{~min}$. Next, the cells were incubated for $1 \mathrm{~h}$ at RT with the appropriate primary antibodies, rinsed several times, and incubated at RT for $30 \mathrm{~min}$ with the corresponding fluorescent secondary antibodies. DAPI was used for nuclei detection. Fluorescence images were captured with a Nikon ECLIPSE 80i microscope.

\section{In vivo xenograft assay}

Animal experiments were carried out as previously described [54]. For tumor engraftment, $6 \times 10^{5}$ tumor cells were injected onto the right flanks or tail vein of female BALB/c nude mice (Harlan) in our pathogen-free animal facility. All experimental procedures using animals were previously reviewed and approved by the Institutional
Animal Care and Use Committee (IACUC) at the Cancer Hospital of Chinese Academy of Medical Science. For right flank-injected nude mice, tumor volume was calculated using the formula $0.5 \times \mathrm{A} \times \mathrm{B}^{2}$, where $\mathrm{A}$ is the length of the tumor, and $\mathrm{B}$ is the width.

\section{Immunohistochemical staining}

For immunohistochemical staining, paraffinembedded unstained slides from mice were incubated with an antibody against stathmin, Ki67, keratin 17 or control immunoglobulin $\mathrm{G}$ (IgG; $1 \mathrm{mg} / \mathrm{ml})$. After washing with $1 \times$ PBS, slides were incubated with a biotin-labeled secondary antibody. Signals were visualized using an ultrasensitive streptavidin-peroxidase system (Maxim Biotech).

\section{Microarray and real-time PCR analysis}

Total RNA was isolated from untreated and stathmin overexpression KYSE 170 and parent cells using an RNeasy ${ }^{\circledR}$ mini kit (Qiagen). The quality of the total RNA was determined using a NanoDrop spectrophotometer (ND-2000; Thermo Fisher Scientific). RNA with an A260/A280 absorbance ratio ranging from 1.8 to 2.0 was used for cDNA synthesis. Gene expression profiles were analyzed on a GeneChip ${ }^{\circledR}$ Human Genome U133 Plus 2.0 array (Affymetrix, Santa Clara, CA), which contains 54,000 probe sets representing approximately 47,000 genes. The signal intensity of the gene expression was analyzed to generate CEL files using the default setting of Affymetrix ${ }^{\circledR}$ GeneChip ${ }^{\circledR}$ Command Console ${ }^{\circledR} 3.2$ (AGCC) software. The Affymetrix Microarray Suite 5.0 (MAS5) and the Robust Multi-array Average (RMA) algorithm were used for the expression summary and signal calculation of the GeneChip ${ }^{\circledR}$ Human Genome U133 2.0 data [55], respectively. Differentially expressed genes were selected based on a $>2.0$-fold change and a $\mathrm{q}$ value $<5 \%$. Entrez gene identifiers were used to perform enrichment analysis using the Database for Annotation, Visualization and Integrated Discovery (DAVID) and the online database resource Search Tool for the Retrieval of Interacting Genes (STRING). Fold change was calculated relative to the average of the control group. The primer sequences are provided in Table 2 .

Total RNA was isolated from stathminoverexpression KYSE170 and parent cells, and firststrand reverse transcription was performed using the SuperScript ${ }^{\circledR}$ III Reverse Transcriptase kit (Invitrogen, USA). Primers were designed with Primer-Blast software (http://www.ncbi.nlm.nih.gov/tools/primerblast/). Amplification reactions were conducted using the SsoFastTMEvaGreen ${ }^{\circledR}$ Supermix with a CFX 96TM RealTime System (Chemoscience, USA). GAPDH served as an internal control to normalize the loading of the template cDNA. Each experiment was repeated at least twice, and 
the fold change in gene expression was assessed using the $\Delta \mathrm{Ct}$ method.

\section{Statistical analysis}

Statistical significance was determined by Student's $\mathrm{t}$ test performed with or without Welch's correction for unequal variance using GraphPad Prism Version 6.05 (GraphPad Software, Inc., La Jolla, CA). Significance testing for tumor growth over time was performed using repeated measures two-way Anova with Tukey multiple comparisons of means as a post hoc test to evaluate differences between groups. In some cases, tumor volumes were compared at each time point using Student's t test with the Holm-Šidák method to correct for multiple comparisons.

\section{ACKNOWLEDGMENTS}

We thank Professor Yutaka Shimada at Hyogo College of Medicine for providing the KYSE 180, KYSE 510, KYSE 30, KYSE 140, KYSE 150, KYSE 170 and KYSE 410 cell lines.

\section{CONFLICTS OF INTEREST}

The authors have declared that no competing interests exist.

\section{GRANT SUPPORT}

This work was supported by grants from the National Natural Science Foundation (81372385, 81572365,81372591 and 91629105), the State Key Project for Basic Research (2014BAI09B07, 2016YFC0901400, and 2014CBA02002) of China and the CAMS Innovation Fund for Medical Sciences (2016I2M-1-001)

\section{REFERENCES}

1. Torre LA, Bray F, Siegel RL, Ferlay J, Lortet-Tieulent J, Jemal A. Global cancer statistics, 2012. CA Cancer J Clin. 2015; 65: 87-108.

2. Zhu ML, Shi TY, Hu HC, He J, Wang M, Jin L, Yang YJ, Wang JC, Sun MH, Chen H, Zhao KL, Zhang Z, Chen HQ, et al. Polymorphisms in the ERCC5 gene and risk of esophageal squamous cell carcinoma (ESCC) in eastern Chinese populations. PLoS One. 2012; 7: e41500.

3. Qiu H, Mao Y, Gu Y, Zhu J, Wang Y, Zeng J, Huang N, Liu Q, Yang Y. The potential of photodynamic therapy to treat esophageal candidiasis coexisting with esophageal cancer. J Photochem Photobiol B. 2014; 130: 305-309.

4. Gupta GP, Massagué J. Cancer metastasis: building a framework. Cell. 2006; 127: 679-695.
5. Worni M, Martin J, Gloor B, Pietrobon R, D'Amico TA, Akushevich I, Berry MF. Does surgery improve outcomes for esophageal squamous cell carcinoma? An analysis using the surveillance epidemiology and end results registry from 1998 to 2008. J Am Coll Surg. 2012; 215: 643-651.

6. Wang XB, Jiang XR, Yu XY, Wang L, He S, Feng FY, Guo LP, Jiang W, Lu SH. Macrophage inhibitory factor 1 acts as a potential biomarker in patients with esophageal squamous cell carcinoma and is a target for antibody-based therapy. Cancer Sci. 2014; 105: 176-185.

7. Schoumacher M, Goldman RD, Louvard D, Vignjevic DM. Actin, microtubules, and vimentin intermediate filaments cooperate for elongation of invadopodia. J Cell Biol. 2010; 189: $541-556$.

8. Nouar R, Breuzard G, Bastonero S, Gorokhova S, Barbier P, Devred F, Kovacic H, Peyrot V. Direct evidence for the interaction of stathmin along the length and the plus end of microtubules in cells. FASEB J. 2016; 30: 3202-3215.

9. Gupta KK, Li C, Duan A, Alberico EO, Kim OV, Alber MS, Goodson HV. Mechanism for the catastrophe-promoting activity of the microtubule destabilizer Op18/stathmin. Proc Natl Acad Sci U S A. 2013; 110: 20449-20454.

10. Hanash SM, Strahler JR, Kuick R, Chu EH, Nichols D. Identification of a polypeptide associated with the malignant phenotype in acute leukemia. J Biol Chem. 1988; 263: 12813-12815.

11. Schubart UK. Regulation of protein phosphorylation in hamster insulinoma cells. Identification of $\mathrm{Ca} 2+$-regulated cytoskeletal and cAMP-regulated cytosolic phosphoproteins by two-dimensional electrophoresis. J Biol Chem. 1982; 257: 12231-12238.

12. Chen J, Abi-Daoud M, Wang A, Yang X, Zhang X, Feilotter HE, Tron VA. Stathmin 1 is a potential novel oncogene in melanoma. Oncogene. 2013; 32: 1330-1337.

13. Werner HM, Trovik J, Halle MK, Wik E, Akslen LA, Birkeland E, Bredholt T, Tangen IL, Krakstad C, Salvesen HB. Stathmin protein level, a potential predictive marker for taxane treatment response in endometrial cancer. PLos One. 2014; 9: e90141.

14. Kuang XY, Chen L, Zhang ZJ, Liu YR, Zheng YZ, Ling H, Qiao F, Li S, Hu X, Shao ZM. Stathmin and phosphostathmin protein signature is associated with survival outcomes of breast cancer patients. Oncotarget. 2015; 6: 22227-22238. doi: 10.18632/oncotarget.4276.

15. Watanabe A, Suzuki H, Yokobori T, Tsukagoshi M, Altan B, Kubo N, Suzuki S, Araki K, Wada S, Kashiwabara K, Hosouchi Y, Kuwano H. Stathmin1 regulates p27 expression, proliferation and drug resistance, resulting in poor clinical prognosis in cholangiocarcinoma. Cancer Sci. 2014; 105: 690-696.

16. Wik E, Birkeland E, Trovik J, Werner HM, Hoivik EA, Mjos S, Krakstad C, Kusonmano K, Mauland K, Stefansson IM, Holst F, Petersen K, Oyan AM, et al. High phosphostathmin(serine38) expression identifies aggressive 
endometrial cancer and suggests an association with PI3K inhibition. Clin Cancer Res. 2013; 19: 2331-2341.

17. Belletti B, Baldassarre G. Stathmin: a protein with many tasks. New biomarker and potential target in cancer. Expert Opin Ther Targets. 2011; 15: 1249-1266.

18. Wang S, Akhtar J, Wang Z. Anti-STMN1 therapy improves sensitivity to antimicrotubule drugs in esophageal squamous cell carcinoma. Tumour Biol. 2015; 36: 7797-7806.

19. Liu F, Sun YL, Xu Y, Liu F, Wang LS, Zhao XH. Expression and phosphorylation of stathmin correlate with cell migration in esophageal squamous cell carcinoma. Oncol Rep. 2013; 29: 419-424.

20. Wang F, Wang LX, He W, Zhu LN, Zhao PR, Fan QX. [Expression of stathmin in esophageal squamous cell carcinoma and its biological significance]. [Article in Chinese]. Nan Fang Yi Ke Da Xue Xue Bao. 2010; 30: 1552-1557.

21. Akhtar J, Wang Z, Yu C, Zhang ZP, Bi MM. STMN-1 gene: a predictor of survival in stage iia esophageal squamous cell carcinoma after Ivor-Lewis esophagectomy? Ann Surg Oncol. 2014; 21: 315-321.

22. Akhtar J, Wang Z, Jiang WP, Bi MM, Zhang ZP. Stathmin overexpression identifies high risk for lymphatic metastatic recurrence in pN0 esophageal squamous cell carcinoma patients. J Gastroenterol Hepatol. 2014; 29: 944-950.

23. Bianchi L, Costanza G, Campione E, Ruzzetti M, Di Stefani A, Diluvio L, Giardina E, Cascella R, CordialiFei P, Bonifati C, Chiricozzi A, Novelli G, Ensoli F, et al. Biomolecular index of therapeutic efficacy in psoriasis treated by anti-TNF alpha agents. G Ital Dermatol Venereol. 2016 Sep 14. [Epub ahead of print].

24. Chen R, Fu M, Zhang G, Zhou Y, Zhu S, Liu J, Wang D, Deng A, Wang Z. Rac1 regulates skin tumors by regulation of keratin 17 through recruitment and interaction with CD11b+Gr1+ cells. Oncotarget. 2014; 5: 4406-4417. doi: 10.18632/oncotarget.2030.

25. Wright SD, Meyer BC. Fibronectin receptor of human macrophages recognizes the sequence Arg-Gly-Asp-Ser. J Exp Med. 1985; 162: 762-767.

26. Mana G, Clapero F, Panieri E, Panero V, Böttcher RT, Tseng HY, Saltarin F, Astanina E, Wolanska KI, Morgan MR, Humphries MJ, Santoro MM, Serini G, Valdembri D. PPFIA1 drives active $\alpha 5 \beta 1$ integrin recycling and controls fibronectin fibrillogenesis and vascular morphogenesis. Nat Commun. 2016; 7: 13546.

27. Nojima Y, Morino N, Mimura T, Hamasaki K, Furuya H, Sakai R, Sato T, Tachibana K, Morimoto C, Yazaki Y, Hirai H. Integrin-mediated cell adhesion promotes tyrosine phosphorylation of p130Cas, a Src homology 3-containing molecule having multiple Src homology 2-binding motifs. J Biol Chem. 1995; 270: 15398-15402.

28. Lin $\mathrm{CH}$, Lin HH, Kuo CY, Kao SH. Aeroallergen Der $\mathrm{p}$ 2 promotes motility of human non-small cell lung cancer cells via toll-like receptor-mediated up-regulation of urokinase-type plasminogen activator and integrin/focal adhesion kinase signaling. Oncotarget. 2017; 8: 1131611328. doi: 10.18632/oncotarget.14514.

29. Liu C, Kaneko S, Soma K. Expression of integrinalpha5beta1, focal adhesion kinase and integrinlinked kinase in rat condylar cartilage during mandibular lateral displacement. Arch Oral Biol. 2008; 53: 701-708.

30. Shimada Y, Watanabe G, Kawamura J, Soma T, Okabe M, Ito T, Inoue H, Kondo M, Mori Y, Tanaka E, Imamura M. Clinical significance of osteopontin in esophageal squamous cell carcinoma: comparison with common tumor markers. Oncology. 2005; 68: 285-292.

31. Lin DC, Du XL, Wang MR. Protein alterations in ESCC and clinical implications: a review. Dis Esophagus. 2009; 22: 9-20.

32. Brockmann JG, St Nottberg H, Glodny B, Heinecke A, Senninger NJ. CYFRA 21-1 serum analysis in patients with esophageal cancer. Clin Cancer Res. 2000; 6: 4249-4252.

33. Bhagirath D, Abrol N, Khan R, Sharma M, Seth A, Sharma A. Expression of CD147, BIGH3 and stathmin and their potential role as diagnostic marker in patients with urothelial carcinoma of the bladder. Clin Chim Acta. 2012; 413: 1641-1646.

34. Yousefi Z, Sarvari J, Nakamura K, Kuramitsu Y, Ghaderi A, Mojtahedi Z. Secretomic analysis of large cell lung cancer cell lines using two-dimensional gel electrophoresis coupled to mass spectrometry. Folia Histochem Cytobiol. 2012; 50: 368-374.

35. Fife CM, Sagnella SM, Teo WS, Po'uha ST, Byrne FL, Yeap YY, Ng DC, Davis TP, McCarroll JA, Kavallaris M. Stathmin mediates neuroblastoma metastasis in a tubulinindependent manner via RhoA/ROCK signaling and enhanced transendothelial migration. Oncogene. 2017; 36: 501-511.

36. Byrne FL, Yang L, Phillips PA, Hansford LM, Fletcher JI, Ormandy CJ, McCarroll JA, Kavallaris M. RNAimediated stathmin suppression reduces lung metastasis in an orthotopic neuroblastoma mouse model. Oncogene. 2014; 33: 882-890.

37. Akiyama SK, Olden K, Yamada KM. Fibronectin and integrins in invasion and metastasis. Cancer Metastasis Rev. 1995; 14: 173-189.

38. Ruoslahti E. Cell adhesion and tumor metastasis. Princess Taka-Matsu. Symposium. 1994; 24: 99-105.

39. Hynes RO. Integrins: bidirectional, allosteric signaling machines. Cell. 2002; 110: 673-687.

40. Jiang Q, Pan Y, Cheng Y, Li H, Liu D, Li H. Lunasin suppresses the migration and invasion of breast cancer cells by inhibiting matrix metalloproteinase-2/-9 via the FAK/Akt/ ERK and NF- $\mathrm{BB}$ signaling pathways. Oncol Rep. 2016; 36: 253-262.

41. Dia VP, Gonzalez de Mejia E. Lunasin potentiates the effect of oxaliplatin preventing outgrowth of colon cancer metastasis, binds to $\alpha 5 \beta 1$ integrin and suppresses FAK/ ERK/NF-кB signaling. Cancer Lett. 2011; 313: 167-180. 
42. Vitorino P, Yeung S, Crow A, Bakke J, Smyczek T, West K, McNamara E, Eastham-Anderson J, Gould S, Harris SF, Ndubaku C, Ye W. MAP4K4 regulates integrin-FERM binding to control endothelial cell motility. Nature. 2015; 519: 425-430.

43. Kessler BE, Sharma V, Zhou Q, Jing X, Pike LA, Kerege AA, Sams SB, Schweppe RE. FAK expression, not kinase activity, is a key mediator of thyroid tumorigenesis and protumorigenic processes. Mol Cancer Res. 2016; 14: 869-882.

44. Mythreye K, Knelson EH, Gatza CE, Gatza ML, Blobe GC. T $\beta$ RIII/ $\beta$-arrestin 2 regulates integrin $\alpha 5 \beta 1$ trafficking, function, and localization in epithelial cells. Oncogene. 2013; 32: 1416-1427.

45. Gardel ML, Schneider IC, Aratyn-Schaus Y, Waterman CM. Mechanical integration of actin and adhesion dynamics in cell migration. Annu Rev Cell Dev Biol. 2010; 26: 315-333.

46. Dia VP, Gonzalez de Mejia E. Lunasin induces apoptosis and modifies the expression of genes associated with extracellular matrix and cell adhesion in human metastatic colon cancer cells. Mol Nutr Food Res. 2011; 55: 623-634.

47. Levental KR, Yu H, Kass L, Lakins JN, Egeblad M, Erler JT, Fong SF, Csiszar K, Giaccia A, Weninger W, Yamauchi M, Gasser DL, Weaver VM. Matrix crosslinking forces tumor progression by enhancing integrin signaling. Cell. 2009; 139: 891-906.

48. Lopez-Bergami P, Huang C, Goydos JS, Yip D, Bar-Eli M, Herlyn M, Smalley KS, Mahale A, Eroshkin A, Aaronson $\mathrm{S}$, Ronai Z. Rewired ERK-JNK signaling pathways in melanoma. Cancer Cell. 2007; 11: 447-460.
49. Lee YS, Kim SY, Song SJ, Hong HK, Lee Y, Oh BY, Lee WY, Cho YB. Crosstalk between CCL7 and CCR3 promotes metastasis of colon cancer cells via ERK-JNK signaling pathways. Oncotarget. 2016; 7: 36842-36853. doi: 10.18632/oncotarget.9209.

50. Zhang J, Zhi H, Zhou C, Ding F, Luo A, Zhang X, Sun Y, Wang X, Wu M, Liu Z. Up-regulation of fibronectin in oesophageal squamous cell carcinoma is associated with activation of the erk pathway. J Pathol. 2005; 207: 402-409.

51. Illario M, Cavallo AL, Bayer KU, Di Matola T, Fenzi G, Rossi G, Vitale M. Calcium/calmodulin-dependent protein kinase II binds to Raf-1 and modulates integrin-stimulated ERK activation. J Biol Chem. 2003; 278: 45101-45108.

52. Yurdagul A Jr, Sulzmaier FJ, Chen XL, Pattillo CB, Schlaepfer DD, Orr AW. Oxidized LDL induces FAKdependent RSK signaling to drive NF- $\mathrm{KB}$ activation and VCAM-1 expression. J Cell Sci. 2016; 129: 1580-1591.

53. Schlaepfer DD, Hanks SK, Hunter T, van der Geer P. Integrin-mediated signal transduction linked to Ras pathway by GRB2 binding to focal adhesion kinase. Nature. 1994; 372: 786-791.

54. Xu Y, Zhou L, Huang J, Liu F, Yu J, Zhan Q, Zhang L, Zhao X. Role of Smac in determining the chemotherapeutic response of esophageal squamous cell carcinoma. Clin Cancer Res. 2011; 17: 5412-5422.

55. Zhao N, Mao Y, Han G, Ju Q, Zhou L, Liu F, Xu Y, Zhao X. YM155, a survivin suppressant, triggers PARP-dependent cell death (parthanatos) and inhibits esophageal squamouscell carcinoma xenografts in mice. Oncotarget. 2015; 6: 18445-18459. doi: 10.18632/oncotarget.4315. 